\title{
TALC INDICES FROM BOUMNYEBEL (CENTRAL - CAMEROON), PHYSICO - CHEMICAL CHARACTERISTICS AND GEOCHEMISTRY
}

Nkoumbou $^{1,3}$ C., Njopwouo $^{2}$ D., Villiéras ${ }^{3}$ F, Njoya ${ }^{1}$ A., Yonta Ngouné $^{1}$ C, Ngo Ndjock $^{2}$ L., Tchoua ${ }^{1}$ F.M. \& Yvon ${ }^{3}$ J.

1 : Laboratoire de Géologie Economique et Environnementale, Département des Sciences de la Terre Sciences, Faculté des Sciences, Université de Yaoundé I, BP. 812, Yaoundé - Cameroun. E-mail : nkoumbouc@yahoo.fr

2: Laboratoire de Physico-Chimie des Matériaux Minéraux, Département de Chimie Inorganique, Faculté des Sciences, Université de Yaoundé I, B.P. 812,Yaoundé-Cameroun.

3 : Laboratoire Environnement et Minéralurgie, UMR 7569, INPL-CNRS, E.N.S.G, 15 avenue du Charmois, B.P. : 40, F-54501 Vandoeuvre-lès-Nancy Cedex, France.

\section{ABSTRACT}

Two talc schist occurrences were discovered in the Boumnyebel area, embedded in the PanAfrican mica schist, at the junction between Archean, Eburnean and Neoproterozoic formations in Cameroon. They have been analysed by different techniques such as chemical analyses, XRD, DRIFTS, DTA and TG. The talc schist of the northern deposit contains talc (up to $95 \mathrm{wt} \%$ ) with chlorite, goethite and lepidocrocite as minor minerals. The talc schist of the southern deposit has up to $88 \%$ of talc and is speckled with dark green phenoblasts of amphiboles (coexisting prismatic tremolite and magnesio-riebeckite). Due to its high talc content, the amphibole-free talc schist is economically attractive. Chemical analyses show that most of the rocks consist of $\mathrm{SiO}_{2}, \mathrm{MgO}$ and $\mathrm{Fe}_{2} \mathrm{O}_{3}$, except the sample from the southern deposit that displays some amounts of $\mathrm{Al}_{2} \mathrm{O}_{3}$ and $\mathrm{CaO}$. Among trace elements, $\mathrm{Ni}, \mathrm{Co}$ and $\mathrm{Cr}$ are as high as in serpentinized peridotites, and suggest a protolith of ultrabasic nature. Chromium concentration in tremolite reaches 6178 ppm; most of the trace elements $(\mathrm{Cd}, \mathrm{Cr}$, Dy, Er, Eu, Ga, Gd, Ho, Lu, Nd, Pr, Sm, Sn, Sr, Tb, Tm, Y, Yb, Zr) are compatible with a tremolite lattice. The regional metamorphism yielded garnet micaschist nappes and thus belongs to the upper greenschist facies. Based on the high talc contents of the rocks and occasional coexisting tremolite and magnesio-riebeckite, the origin of the talc deposits is assigned to a hydrothermal alteration of ultramafic rocks. During the hydrothermal event, the fluid composition changed from silica-rich to lime-rich, but very few trace element contents were affected. Thus the low Rb, Sr, Th, Nb, K, Ta, Y, $\mathrm{Zr}$, Hf, MREE and HREE and high $\mathrm{Ni}, \mathrm{Cr}$, Co contents of the rocks point to depleted peridotites (harzburgite - lherzolite) and pyroxenite as protoliths. The hydrothermal alteration is expressed in the positive cerium anomaly accompanied by little LREE enrichment of talc-rich rocks and hornblendite. The studied talc schist deposits and the neighbouring gabbroic and ultramafic rocks may belong to a dismembered Pan-African ophiolite set. 
Key words: Cameroon, Boumnyebel, talc schist, physico-chemical characteristics, hydrothermal alteration, protolith.

\section{1 - INTRODUCTION}

Physico-chemical and beneficiation studies of clay materials in Cameroon have been carried out on kaolinite, illite, montmorillonite, palygorskite and beidellite (Njopwouo, 1984; Njopwouo et al., 1987, 1988; Elimbi and Njopwouo, 2002) but not on talc. Though talc occurrences are rare in Cameroon, two occurences of talc-rich rocks are reported at Baoina and Mayo Boula in North Cameroon (Laplaine, 1969). Another geological survey of these sites has confirmed their limited volume. They occur as one meter-thick dykes in amphibolite. X-ray diffraction reveals up to $85 \%$ of talc with chlorite, amphiboles, serpentine and diopside as minor minerals and traces of quartz, calcite, dolomite, magnesite and pyrophyllite. At Lomié (Eastern Cameroon), serpentinite resulting from the metasomatic alteration of peridotite displays different types of contacts with the surrounding mica schists and quartzites (e.g. 1: serpentinite - carbonate - mica schist ; 2: serpentinite - talc schist - mica schist; 3: serpentinite - carbonate - talc schist - mica schsit). At most of these contacts, a few metersized talc schists and carbonates are well developed in shear zones and fractures (Ndonguissop et al., 1999), and they may result from the metasomatic alteration of serpentinite during its emplacement; the shear zones acted as pathways for metasomatic fluids. This work presents the first physico-chemical characterisation and geochemical data of large outcrops of talc schist recently discovered in the Boumnyebel area, located 90-100 km west of Yaoundé city.

\section{2 - GEOLOGICAL SETTING}

Boumnyebel area is a key region of the Precambrian orogens in Cameroon. It is located at the junction between (1) the Archean Ntem unit (3.2 to $2.9 \mathrm{Ga}$, Lasserre and Soba, 1976; Tchameni, 1997), (2) the Lower Nyong Unit, a reworked western part of the Archean Ntem Group during the Eburnean orogeny (2.2 - $2.0 \mathrm{Ga}$, Feybesse et al., 1987; Toteu et al., 1994) and (3) the Neoproterozoic migmatitic Yaounde gneisses (Pan-African orogeny, $600 \mathrm{Ma}$ ) (Nzenti et al., 1988; Mvondo et al., 2003) (figure 1a). It is noteworthy that a Pan-African garnet-rich mica schist outlier covers the Yaounde migmatites. Two talc schist occurrences associated with basic and ultramafic rocks, have been discovered in this garnet - mica schist, one NE of Lamal Pougue (figure 1b), the other in the southwest, at Pout Kelle.

\section{3 - EXPERIMENTAL TECHNIQUES}

Two whole-rock samples (one of each outcrop) and amphibole separated from the sample of talc schist from Pout Kelle have been selected for analyses by different techniques: chemical analyses, X-ray diffraction (XRD), Diffuse Reflectance Infrared Fourier Transform Spectroscopy (DRIFTS), Differential Thermal Analyses (DTA) and Thermogravimetric analyses (TGA). Amphibole crystals were hand-sorted and washed with distilled water for one hour using an ultrasonic bath. Then the 
crystals were oven-dried at $105{ }^{\circ} \mathrm{C}$ for one hour. Finally, whole-rock samples and one half of the crystals were crushed in an agate mortar for the above-mentioned analyses. The remaining crystals are yet to be used for microprobe, TEM and SEM analyses. A few crystals were sorted for analyses (XRD, DRIFTS) without washing or drying.

Chemical analyses were obtained at the "Centre de Recherches Pétrographiques et Géochimiques" (Nancy, France) by emission spectrometry, using an inductively coupled plasma source and an atomic emission source (ICP-AES) for major elements, and mass spectrometry (ICP-MS) for trace elements, after fusion with $\mathrm{LiBO}_{2}$ and dissolution in $\mathrm{NHO}_{3}$. Relative analytical uncertainties are estimated at 1 to $2 \%$ for major elements $\left(5 \%\right.$ for $\left.\mathrm{P}_{2} \mathrm{O}_{5}\right)$. They reach $5 \%$ for most of the trace element concentrations except $\mathrm{Cu}$ and $\mathrm{Ni}(10 \%)$. However, uncertainty is high (>10\%) for any trace element displaying low concentration $(<0.1 \mathrm{ppm})$.

XRD and DRIFTS analyses were performed at the "Laboratoire Environnement et Minéralurgie, Ecole Nationale Supérieure de Géologie" (Nancy, France); XRD was performed by reflection on powders, using a D8 Advanced Bruker device, with Co Ka radiation, $35 \mathrm{kV}$ and $45 \mathrm{~mA}$. The data were recorded between $3^{\circ}$ and $70^{\circ}(2 \theta)$, step scan $0.036^{\circ}$, step time $3.0 \mathrm{~s}$. Magnesio-riebeckite was analyzed on a Jobin-Yvon 2080 device with $\mathrm{Cu} \mathrm{K} \alpha$ radiation, $38 \mathrm{kV}$ and $8 \mathrm{~mA}$, step scan $0.050^{\circ}$ and step time $3.0 \mathrm{~s}$. For Infrared spectroscopy, a spectrometer "Bruker IFS 55" was calibrated in a wave number domain between 600 and $4000 \mathrm{~cm}^{-1}$. The powdered sample was diluted in $\mathrm{KBr}$ (50 mg of sample in $350 \mathrm{mg}$ of $\mathrm{KBr}$ ). The spectrum of each sample was recorded by accumulating 200 scans at $4.0 \mathrm{~cm}^{-1}$ resolution.

Thermal analyses (DTA and TG) were carried out at the laboratory of "Groupe d'Etude des Matériaux Hétérogènes" of "Ecole Nationale Supérieure de Céramique Industrielle" (Limoges, France). The investigated temperature ranged from 20 to $1000{ }^{\circ} \mathrm{C}$ in self-generated atmosphere, with continuous recording on a $\mathrm{PC}$ computer. $\mathrm{Al}_{2} \mathrm{O}_{3}$ pre-heated at $1500^{\circ} \mathrm{C}$ served as reference. The heating rate was 10 ${ }^{\circ} \mathrm{C} /$ minute. TG data were completed by sequential analyses at $1050,1100,1150,1200$ and $1250{ }^{\circ} \mathrm{C}$ in self-generated atmosphere, at the Local Material Promotion Authority's laboratory, Yaoundé Cameroon.

\section{4 - FIELD DESCRIPTION AND PETROGRAPHIC FEATURES}

The talc schist of NE Lamal Pougue forms a decametric outcrop associated with quartzites and orthoamphibolite (figure 1b). The sample is nearly white and displays a radiate texture. The rock is almost monomineralic with traces of chlorite and goethite. The talc schist of Pout Kelle occurs on two $50 \mathrm{~m}$ high hills, elongated NE $(200 \times 100 \mathrm{~m})$. Surrounding rocks are mica schist, gneiss, quartzites and ultramafic formations. Samples of talc schist are speckled with dark green amphibole crystals whose dimensions increase from the bottom to the top of the hill $(0.2 \times 1 \mathrm{~cm}$ to $2 \times 15 \mathrm{~cm})$. At this deposit, amphibole-free samples may contain many millimetric to centimetric crystals of pyrite and rutile.

Under the microscope, talc schist from Lamal Pougue is coarse-grained (figure 2a). Most of the elongated crystals are parallel to the schistosity. Chlorite domains are very scarce and few goethite 
crystals are scattered in the rock. In the sample from Pout Kelle, microcrystals of talc form a matrix around euhedral tremolite phenoblasts. This type of relation is interpreted in terms of the development of tremolite crystals at the expense of talc crystals (figure $2 b, c \& d$ ).

\section{5 - PHYSICAL CHARACTERIZATION OF TALC SCHISTS 5 - 1. X-RAY DIFFRACTION}

The X-ray powder pattern of the whole rock sample from NE Lamal Pougue (figure 3a, sample : Mamb) reveals that the talc mineral is mainly associated with chlorite and goethite. The powder pattern of talc schist from Pout Kelle reveals that accessory minerals associated with talc are tremolite, chlorite and lepidocrocite (figure 3a, sample 1GG). All the whole-rock samples patterns are dominated by the $00 \mathrm{l}$ reflections of talc and chlorite as for pure chlorite and talc (Ferrage et al., 2003a). The conspicuous feature of the diffractograms is the thin shape of the reflections at low $2 \theta$ angles, which is indicative of a good crystallinity. The dimensions of coherent scattering thickness of talc and chlorite were deduced from the full-width at half-maximum (FWHM) by applying Scherrer's equation. Measurements were focussed on basal reflections ( $\mathrm{d}_{001}$ for talc and $\mathrm{d}_{002}$ for chlorite). The values obtained (> $1060 \AA$ for talc and $>870 \AA$ for chlorite; table 1$)$ are very high compared to those reported on fairly well ground talc from Trimouns, France (Michot, 1990; Villiéras, 1993) or from Puebla de Lillo, Spain (Sanchez-Soto et al., 1997, Perez-Maqueda et al., 2005) and can be considered as a criterion of good crystallinity.

Separated amphiboles are essentially tremolite showing a few reflections of talc (figure $3 \mathrm{~b}$ ), or magnesio-riebeckite (figure 3c). The separated mineral is estimated to be nearly pure at $>99 \%$ because the centimetre size (up to $15 \mathrm{~cm}$ ) of the crystals favoured a good separation. Talc may have formed interlamellar intergrowths with tremolite. Using a transmission electronic microscope, Müller et al (2003) described a complex lamellar intergrowth between anthophyllite, gedrite, calcic amphibole, cummingtonite, talc and chlorite in a metamorphosed ultramafic rock at the KTB pilot hole, Bavaria (Germany). Moreover, studies on high resolution techniques have established that most amphibole crystals displaying virtual homogeneity under the microscope can contain some pyribole chains or phyllosilicate plates in their microstructure (Ghose, 1981). Thus, talc fingerprints encountered here can correspond to such an irregular structure in tremolite.

\section{5 - 2. DIFFERENTIAL THERMAL ANALYSES}

In figure 4, the thermogram of talc schist from NE Lamal Pougue (sample : Mamb) shows an exothermic loop from the beginning to $400{ }^{\circ} \mathrm{C}$. Within this loop, an endothermic peak occurs at about $300{ }^{\circ} \mathrm{C}$ and may correspond to the dehydroxylation of goethite and lepidocrocite, yielding hematite and maghemite, respectively. The endothermic phenomenon can result from nitrogen desorption, since 
nitrogen displays a high affinity for the proton of the hydroxyl group (Michot et al., 1990, 1994). Immediately at about $320^{\circ} \mathrm{C}$, a small exothermic peak can be attributed to the transformation of maghemite $\left(\gamma-\mathrm{Fe}_{2} \mathrm{O}_{3}\right)$ into hematite $\left(\alpha-\mathrm{Fe}_{2} \mathrm{O}_{3}\right)$, according to Gehring and Hofmeister (1994). The main endothermic peak, resulting from talc dehydroxylation, begins at $800^{\circ} \mathrm{C}$, its maximum occurs at about $980{ }^{\circ} \mathrm{C}$ (Villieras, 1993; Bose and Ganguly, 1994).

On the thermogram of the talc schist from Pout Kelle (figure 4, sample 1GG), the small endothermic peak, observed between 50 and $100^{\circ} \mathrm{C}$ can be assigned to the desorption of hydration water. Between 100 and $370{ }^{\circ} \mathrm{C}$, an exothermic loop may be caused by the release of nitrogen as stated earlier. At about $500{ }^{\circ} \mathrm{C}$, the slope bends gently, an endothermic change of slope appears at $850{ }^{\circ} \mathrm{C}$ when talc begins to dehydroxylate. The high stability of talc up to $980{ }^{\circ} \mathrm{C}$ confirms the good crystallinity revealed by the coherent scattering thickness data.

\section{5 - 3. THERMOGRAVIMETRIC ANALYSES}

Most of the reactions, specially those involving the loss of combined water or the dehydroxylation of molecules, deduced from the differential thermal analyses are marked by weight loss (figure 5). All the results of thermogravimetric analyses are presented in table 2. Results are interpreted according to Villiéras (1993) keeping in mind the reactions deduced from the differential thermal analyses.

\section{6 - MINERAL CRYSTAL - CHEMISTRY CHARACTERIZATION 6 - 1. IR SPECTROSCOPY}

The infrared spectra of the whole-rock and separated amphibole samples are given in figure 6. Many important absorption bands occur in the $3700-3600 \mathrm{~cm}^{-1}$ range. Minerals constituting the talc schists have very close absorption bands of $\mathrm{OH}$ over this interval. Consequently, some absorption bands have overlapped. However, the high proportions of talc (table 3) may have yielded huge bands which have covered some bands of accessory chlorite and tremolite in the $3700-3600 \mathrm{~cm}^{-1}$ interval. The low absorption band intensity at $3674 \mathrm{~cm}^{-1}$ of the amphibole separates corroborates this assumption. Therefore, the prominent bands observed at $3676,3660,3643$ and $3621 \mathrm{~cm}^{-1}$ on the enlarged section of the spectra (figure 6a) are the fundamental $\mathrm{OH}$ stretching bands of talc. From the experiments on synthetic talcs by Wilkins and Ito (1967) and the rich collection of Farmer (1974), one of the most recent works on analyses of natural talcs having various compositions was published by Petit et al. (2004). Their data are in good agreement with the data on these synthetic talcs and with the simulated spectra of 2:1 trioctahedral minerals of the talc type (Scholtzova et al., 2003). The three sets of data are used as standard for absorption band assignments : $3676 \mathrm{~cm}^{-1} / \mathrm{vMg}_{3} \mathrm{OH} ; 3660 \mathrm{~cm}^{-1} / \mathrm{vMg}_{2} \mathrm{FeOH}$; $3643 \mathrm{~cm}^{-1} / v \mathrm{MgFe}_{2} \mathrm{OH}$; and $3621 \mathrm{~cm}^{-1} / v \mathrm{Fe}_{3} \mathrm{OH}$. There is a small absorption band at $2710 \mathrm{~cm}^{-1}$ corresponding to OD surrounded by $3 \mathrm{Mg}$ atoms, according to de Donato et al. $(1993,2004)$. The conclusion of these authors on the environment of OD vibrators observed at natural dilution by 
DRIFTS relies on the results of the experiments of Ferrage et al. (2003b), on artificial deuteration of talc. The latter demonstrated that H-D exchange occurs only on the lateral surfaces and not on the basal surfaces at their experimental conditions $\left(200^{\circ} \mathrm{C}, 1 \mathrm{~atm}\right)$. The studied samples display notable $\mathrm{Ni}$ contents (2000 ppm) but also huge amounts of $\mathrm{Fe}$, with $\mathrm{Fe} / \mathrm{Ni}$ ratios up to 20-23, so that the contribution of $\mathrm{Ni}$ to these substitutions may be low. It is not obvious that this ratio is that of talc mineral since part of the iron is provided by goethite. But iron from goethite can be put in parallel with the high partition of Ni into goethite (Manceau et al., 2000) and chlorite (Noack and Colin, 1986). Some amount of $\mathrm{Ni}$ is found in tremolite (see below). Due to the this distribution of $\mathrm{Ni}$ in minerals, the amount of $\mathrm{Ni}$ in talc may be low, leading to a high $\mathrm{Fe} / \mathrm{Ni}$ ratio.

However, at high and low wave numbers, specific bands of accessory minerals are well expressed. A small absorption band at $3697 \mathrm{~cm}^{-1}$ is usually assigned to brucite (Frost and Kloprogge, 1999). Those of chlorite are centred at 3610 and $3589 \mathrm{~cm}^{-1}$ (Villiéras, 1993). The band of goethite at $3131 \mathrm{~cm}^{-1}$ (Weckler and Lutz, 1998) is hidden by the loop of water (Lappi et al., 2004).

In the separated amphibole minerals (figure 6b), the absorption band at $3674 \mathrm{~cm}^{-1}$ is characteristic of the OH-strectching spectrum of tremolite (Della Ventura et al., 2003). The occurrence of several additional bands in the $\mathrm{OH}$-spectrum at both higher and lower frequencies relative to the sharp band of tremolite centred at $3675 \mathrm{~cm}^{-1}$, can be explained by the presence of a pargasite component (Della Ventura et al., 2003). The shoulder at 3623 (around $3625 \mathrm{~cm}^{-1}$ ) is characteristic of a low pargasitic component in solid solution with tremolite. But chemical analysis points to traces of magnesiohornblende and edenite in solid solution (see below). Si-O stretching bands occur between 1100 and $900 \mathrm{~cm}^{-1}$. It is noteworthy that these tremolite and magnesio-riebeckite spectra show notable absorption bands of water between 1700 and $1600 \mathrm{~cm}^{-1}$.

\section{6 - 2 CHEMICAL ANALYSIS OF SEPARATED AMPHIBOLE}

The separated amphibole is a calcic amphibole, a tremolite located midway on the continuum tremolite - magnesio-hornblende. The structural formula calculated following the method proposed by

Leake et al. (1997, appendix 2) is $\left[\mathrm{Na}_{0,018}\right]_{\mathrm{A}} \quad\left(\mathrm{Fe}^{2+}{ }_{0.081} \mathrm{Mn}_{0.031} \mathrm{Ca}_{1.756} \mathrm{Na}_{0.132}\right)_{\mathrm{B}}$ $\left(\mathrm{Fe}^{2+}{ }_{0.422} \mathrm{Mg}_{4.044} \mathrm{Cr}_{0.103} \mathrm{Ni}_{0.01} \mathrm{Fe}^{3+}{ }_{0.421}\right)_{\mathrm{C}}\left[\mathrm{Fe}^{3+}{ }_{0.053} \mathrm{Al}_{0.5} \mathrm{Si}_{7.447}\right]_{\mathrm{T}} \mathrm{O}_{22}(\mathrm{OH})_{2}$ (table 4). When the compatibility of trace elements is expressed through the tremolite / whole-rock partition coefficients (table 5), it appears that most of the trace elements and REE are highly concentrated in the tremolite crystals. Chromium concentration is $6178 \mathrm{ppm}\left(0.90 \mathrm{wt} \% \mathrm{Cr}_{2} \mathrm{O}_{3}\right)$. High partition coefficients are observed for HREE (figure 7). Negative anomalies are displayed by $\mathrm{Ba}$ and $\mathrm{Ce}$ (figure 7). $\mathrm{Pb}$ and $\mathrm{Th}$ are nearly equally distributed between the amphibole crystals and the rock. Many trace elements detected in the mineral (Cd, Dy, Eu, In, Sn, Sr, Zr) were under the limit of detection in the whole-rock samples and their partition coefficients could not be estimated although they are highly compatible with tremolite lattice (table 5). Ce shows a positive anomaly in the chondrite - normalized REE pattern (figure 8). 


\section{7 - MODAL COMPOSITIONS OF TALC SCHISTS}

Qualitative mineralogical compositions of the talc schists are well established through XRD, DTA, TG and DRIFTS studies. In the next step, we investigated the modal compositions of the talc schists using XRD, TG data and chemical analyses.

Semi-quantitative proportions of minerals were calculated from XRD data (Intensities measurements without absorption correction) and the results show that talc proportions are as high as $88-94 \%$ (table 3). Mixture of minerals with some having preferential orientation, and the absence of standards constitute the major difficulties related to the XRD method. Referring to Moore and Reynolds (1997), results higher than $20 \%$ may be affected by an error of $\pm 10 \%$ and mineral amounts lower than $20 \%$, by an error of $\pm 20 \%$. However, as it appears below, the results obtained by the XRD method are reconfirmed by those yielded by other methods.

Mineral contents are also estimated from TG analyses and the results are similar to the compositions obtained from XRD data (table 3). Few difficulties are linked to the TG method because there is no distinction between the dehydroxylation of goethite and that of lepidocrocite. Also, as stated earlier, the surface of natural talc exhibits strong affinity towards nitrogen and organic molecules, which are released between 100 and $500{ }^{\circ} \mathrm{C}$ on heating (Michot et al., 1994). It was not possible to determine the weight loss related to their release. At high temperature, dehydroxylations of talc and tremolite overlap.

Modal compositions are also calculated from chemical analyses according to the methods developed by Yvon et al. (1982, 1990). As only chemical composition of tremolite was available, theoritical chemical compositions of clinochlore, talc (talc + minesotaite end-members) and goethite were used. The results are listed in table 3 and they strengthen the high percentages of talc $(>84 \%)$. The substitution coefficients of $\mathrm{Mg}$ by $\mathrm{Fe}^{2+}$ in talc have been established following the method described by Yvon et al. (1990). In talc schist from Lamal Pougue, the talc structural formula is $\left[\mathrm{Mg}_{2.8} \mathrm{Fe}_{0.2} \mathrm{Si}_{4} \mathrm{O}_{10}(\mathrm{OH})_{2}\right]$ while that of talc from Pout Kelle is $\left[\mathrm{Mg}_{2.77} \mathrm{Fe}_{0.23} \mathrm{Si}_{4} \mathrm{O}_{10}(\mathrm{OH})_{2}\right]$.

\section{8 - GEOCHEMISTRY OF TALC SCHISTS}

Chemical analyses show that all the whole-rock samples are made up of $\mathrm{SiO}_{2}(59 \%), \mathrm{MgO}(27.5-$ $28.5 \%)$ and $\mathrm{FeO}(5.5-6.6 \%)$. Their characteristic features are the very low aluminium and alkaline element contents, [respectively $\mathrm{Al}_{2} \mathrm{O}_{3}<1.2 \%$, and $\left(\mathrm{Na}_{2} \mathrm{O}+\mathrm{K}_{2} \mathrm{O}\right)<0.1 \%$ ]; $\mathrm{TiO}_{2}$ is under the detection limit (table 4). Schandl et al. (2002) studied talc-rich rocks from the Eastern Desert of Egypt and found that they are very poor in $\mathrm{Ni}, \mathrm{Co}$ or $\mathrm{Cr}(0-40 \mathrm{ppm})$, although they have high $\mathrm{MgO}$ and low $\mathrm{Al}_{2} \mathrm{O}_{3}$ concentrations. They concluded that these features preclude mafic or ultramafic protoliths. At Boumnyebel, among trace elements (table 5), Ni (2000 \pm 50 ppm), Co (90 - $100 \mathrm{ppm})$ and $\mathrm{Cr}$ (3600 \pm $10 \mathrm{ppm}$ ) contents are as high as in ultramafic rocks when compared to the serpentinized peridotites of Lomie, East Cameroon (Seme Mouangue, 1998). These values are similar to those obtained in 
harzburgites and dunites from the Eastern Alps (Melcher et al. (2002) or in the ophiolites of Turkey (Yigitbas et al., 2004). It can be suggested that the protolith of the talc-rich rocks of Boumnyebel had a high ultrabasic affinity. $\mathrm{Mg}$ number (molar $100 \mathrm{Mg} /-\mathrm{Mg}+\mathrm{Fe}^{\text {total }}$ ) is as high as 90 . Amphibole-free talc contains up to $26 \mathrm{ppm}$ of $\mathrm{Cu}$ while amphibole-bearing talc has an elevated $\mathrm{Zn}$ content ( $268 \mathrm{ppm})$. The rocks are very poor in rare earth elements when compared to the CI chondrite composition reported by McDonough and Sun (1995). Only Ce shows an enrichment in all rocks (figure 8). LREE plot slightly above 1 times chondrite while middle and heavy REE plot at $<1$ times chondrite. The REE pattern of a hornblendite sampled near the tremolite-bearing talc is also shown. There is an enrichment in LREE with a gentle slope from $\mathrm{La}$ to $\mathrm{Sm}\left(\mathrm{La}_{\mathrm{N}} / \mathrm{Sm}_{\mathrm{N}}=3.71\right.$ and $\left.\mathrm{Eu} / \mathrm{Eu}^{*}=0.92\right)$ and the rest are flat, at 7 times chondrite. Extended rare earth patterns involving other trace elements are plotted with values normalized to the composition of primitive upper mantle recommended by McDonough and Sun (1995). In a geochemical study of ultrabasic rocks from the Eastern Alps, Melcher et al. (2002) arranged the elements according to their bulk distribution coefficients during mantle melting. Although they did not include a few metals ( $\mathrm{W}, \mathrm{Mo}, \mathrm{Pb}, \mathrm{Sb}$ ), we have adopted their element order. The patterns show that the rocks are depleted in almost all trace elements (figure 9). Only $\mathrm{Ba}$ and $\mathrm{Ce}$ show positive anomalies. Rb, U, K, Sr, Nb, Ta, Hf, Pb, Eu, Gd, Dy and Zr concentrations are lower than the limits of detection (table 5). The hornblendite displays high normalized values but its pattern mimics those of talc schists. Negative anomalies in talc schists are well expressed for $\mathrm{Nb}-\mathrm{K}-\mathrm{Ta}, \mathrm{Sr}$, and $\mathrm{Zr}-\mathrm{Hf}$ (figure 9).

\section{9 - DISCUSSION}

\section{Main mineral features}

Petrographical observations, physico-chemical characterizations and chemical analyses lead to concordant result on the great proportions of talc ( $>90 \mathrm{wt} \%)$ in these rocks. Their deposits crop out over hundred of meters (up to $200 \times 100 \mathrm{~m}$; One of newly discovered deposits extends over one kilometer). Generally, in retrograde or low-grade metamorphism, talc is a minor phase among many assemblages (e.g. Müller et al., 2003). For an important deposit displaying such a high talc content, a hydrothermal origin is favoured. Coexisting calcic and sodic amphiboles strengthen the hydrothermal origin. It is mostly in these conditions that amphiboles of different compositions, which may have formed a solid solution in magmas, can crystallise as a result of local saturations. Magnesio-riebeckite is considered to have formed under local saturation of solution by $\mathrm{Si}$ and $\mathrm{Na}$ while for tremolite, the solution was locally saturated by $\mathrm{Si}$ and $\mathrm{Ca}$.

Another important result deduced from chemical data is the ultrabasic nature of the original rocks. Successive metamorphic and hydrothermal reactions have replaced or dissolved all primary minerals which were likely olivine and pyroxenes (see section on protoliths). Basically, some possible reactions for talc and tremolite crystallisation subsequent to olivine and pyroxene replacement are: 
$2 \mathrm{Mg}_{2} \mathrm{SiO}_{4}+3 \mathrm{H}_{2} \mathrm{O}=\mathrm{Mg}_{3} \mathrm{Si}_{2} \mathrm{O}_{5}(\mathrm{OH})_{4}+\mathrm{Mg}(\mathrm{OH})_{2}$

Forsterite water serpentine brucite

(Deer et al., 1992)

$2 \mathrm{CaMgSi}_{2} \mathrm{O}_{6}+3 \mathrm{Mg}_{2} \mathrm{Si}_{2} \mathrm{O}_{6}+3 \mathrm{H}_{2} \mathrm{O}=\mathrm{Ca}_{2} \mathrm{Mg}_{5} \mathrm{Si}_{8} \mathrm{O}_{22}(\mathrm{OH})_{2}+\mathrm{Mg}_{3} \mathrm{Si}_{2} \mathrm{O}_{5}(\mathrm{OH})_{4}$

Diopside enstatite water tremolite serpentine

Fluid coming from the surrounding mica schist may be rich in dissolved $\mathrm{SiO}_{2}$.

$\mathrm{Mg}_{3} \mathrm{Si}_{2} \mathrm{O}_{5}(\mathrm{OH})_{4}+\quad 2 \mathrm{SiO}_{2}=\quad \mathrm{Mg}_{3} \mathrm{Si}_{4} \mathrm{O}_{10}(\mathrm{OH})_{2}+\mathrm{H}_{2} \mathrm{O}$

Serpentine fluid talc fluid

The presence of brucite is shown by infrared data. Since the hydrothermal fluid is silica-saturated in the studied case, brucite may be unstable and the possible reactions are shown below :

$$
\begin{aligned}
& 2 \mathrm{Mg}_{3} \mathrm{Si}_{2} \mathrm{O}_{5}(\mathrm{OH})_{4}=\mathrm{Mg}_{3} \mathrm{Si}_{4} \mathrm{O}_{10}(\mathrm{OH})_{2}+3 \mathrm{Mg}(\mathrm{OH})_{2} \\
& \text { Serpentine talc brucite } \\
& 3 \mathrm{Mg}(\mathrm{OH})_{2}+4 \mathrm{SiO}_{2}=\mathrm{Mg}_{3} \mathrm{Si}_{4} \mathrm{O}_{10}(\mathrm{OH})_{2}+2 \mathrm{H}_{2} \mathrm{O} \\
& \text { Brucite fluid talc fuid }
\end{aligned}
$$

Amphibole crystals are euhedral. It can be deduced from their relation with the surrounding talc that they developed at the expense of talc (figure 2b, c, d). In an experiment, Puhan and Metz (1987) established that tremolite can form at the expense of talc if the medium is rich in calcite and silica with a total fluid pressure up to $5 \mathrm{~kb}$. At the Pout-Kelle deposit, carbonate is not yet observed, so we propose a fluid rich in silica and lime :

$$
\begin{aligned}
& 5 \mathrm{Mg}_{3} \mathrm{Si}_{4} \mathrm{O}_{10}(\mathrm{OH})_{2}+6 \mathrm{Ca}^{2+}+4 \mathrm{SiO}_{4}{ }^{4-}+4 \mathrm{H}^{+}=3 \mathrm{Ca}_{2} \mathrm{Mg}_{5} \mathrm{Si}_{8} \mathrm{O}_{22}(\mathrm{OH})_{2}+4 \mathrm{H}_{2} \mathrm{O} \\
& \text { Talc fluid tremolite fluid }
\end{aligned}
$$

These are a few simple reactions. Indeed, in geological conditions, numerous and complex reactions occur owing to the various and changing parameters. Rare magnesioriebeckite crystals encountered attest to the presence of local heterogeneity in the fluid composition at the scale of a few millimeters.

\section{Metamorphism and hydrothermal conditions}

Strictly speaking, P-T conditions of talc formation cannot be accurately established with the available data. Ongoing research will focus on such calibrations (Yonta N.C., Ph.D. in preparation). Nevertheless, reliable intervals can be deduced from the correlation of the mineral assemblages and experimental data. Regional metamorphism affected the area before the hydrothermal event. This regional metamorphism yielded garnet-mica schist. The interval of P-T formation may rely on garnet- 
biotite-muscovite equilibrium which corresponds to the upper limit of the greenschist facies. For the hydrothermal event, reactions (1) to (4) are assumed. Talc crystallises in a wide range of temperature. It cannot thus help to constraint temperature. Its formation is controlled by other factors, particularly silica activity in the fluid phase (Mével, 2003). A most striking feature is the development of tremolite at the expense of talc. The reverse phenomenon is observed in the talc deposits in the Eastern Desert, Egypt (Schandl et al., 2002). Based on the experimental graph of Trommsdorf and Evans (1977), these authors deduced that talc appears at an invariant point at $490{ }^{\circ} \mathrm{C}$ where it coexists with tremolite, forsterite, antigorite and dolomite, when the $\mathrm{CO}_{2}$ mole fraction of the fluid is low $(<0.2)$. In the case of the Pout-Kelle deposit, from the same graph, the absence of olivine and dolomite in the equilibrium implies that the temperature was below $470{ }^{\circ} \mathrm{C}$ and that the fluid was highly dominated by $\mathrm{H}_{2} \mathrm{O}$.

\section{Nature of the protoliths}

In the field, talc schists are associated with mica schist, quartzites and gneiss overlying orthoamphibolites and ultramafic formations. Logically, silica-rich fluid from surrounding granitoids has some amounts of $\mathrm{Na}, \mathrm{Rb}, \mathrm{Ca}, \mathrm{Sr}, \mathrm{K}, \mathrm{Ce}$ and $\mathrm{Ba}$. In an ultramafic medium, they may increase the concentrations of the mentioned elements (contamination or metasomatism) as has occurred locally where magnesio-riebeckite has crystallised. Talc schist samples from Lamal Pougue and Pout-Kelle have high $\mathrm{Ni}, \mathrm{Cr}$ and Co contents (table 5) and low Rb, Sr, Y and $\mathrm{Zr}$. These low concentrations as well as the negative anomalies displayed by $\mathrm{Th}, \mathrm{Nb}-\mathrm{K}-\mathrm{Ta}, \mathrm{Sr}$, and $\mathrm{Zr}-\mathrm{Hf}$ on the spider-diagram (figure 9) likely reflect the protolith features. The $\mathrm{Ni}, \mathrm{Cr}$ and $\mathrm{Co}$ contents can be assigned to high olivine and pyroxene contents of the original rocks (lherzolite - harzburgite). In hornblendite, high $\mathrm{V}, \mathrm{Sr}, \mathrm{Cr}$ and $\mathrm{Zn}$ and low $\mathrm{Ni}$ and $\mathrm{K}_{2} \mathrm{O}$ concentrations point to a clinopyroxene-rich amphibole-bearing protolith. In addition, the U-shape and flat patterns of talqueous rocks and hornblendite, respectively, corroborate that protoliths were peridotites and pyroxenite. Metamorphosed harzburgites and dunites displaying such a pattern are usually interpreted as mantle residua after huge melt extractions (Melcher et al., 2002 and references herein). After the extraction of an important volume of melt, the residue is depleted in LREE. Compare to depleted MORB mantle composition (Workman and Hart, 2005), the protoliths are highly depleted (figure 9). Nevertheless, the conspicuous positive anomaly in cerium accompanied by the enrichment in LREE are assigned to hydrothermal effects. The slope of LREE in the hornblendite may have increased since the pattern of the separated amphibole is flat at 1.5 times chondrite, except for Ce. The increase in silica content of the rock through the development of talc at the expense of olivine and pyroxene has lowered those of $\mathrm{MgO}$ and $\mathrm{FeO}$.

Many other talc deposits and related ultramafic rocks have been newly discovered in this area. These ultramafic rocks and the neighbouring migmatitic gabbroic massives intercalated in the mica schists of the Neoproterozoic orogen in Cameroon may be related to a dismembered Pan-African ophiolite set. 


\section{0 - CONCLUSION}

In the Boumnyebel area, two talc schist occurrences are located in the Pan-African mica schists overlying the Yaounde migmatites, at the junction between Archean (Liberian), Paleoproterozoic (Eburnean) and Neoproterozoic (Pan-African) formations. The talc schist deposit of Pout-Kelle displays huge prismatic amphibole crystals which are not asbestiform. Owing to their high talc contents (95 \& $88 \mathrm{wt} \%$ ) estimated from XRD, thermal and chemical analyses, at least the amphibolefree talc schist is economically attractive. The regional metamorphism yielded garnet-mica schist and thus corresponds to the upper greenschist facies. For the hydrothermal event deduced from the high talc contents (up to $94 \%$ ) of the rocks and occasional coexisting tremolite and magnesio-riebeckite, a temperature interval lower than $470{ }^{\circ} \mathrm{C}$ is suggested for the crystallisation of tremolite at the expense of talc in silica-rich fluid. The increase in silica content of the rock through the development of talc at the expense of olivine and pyroxene has lowered those of $\mathrm{MgO}$ and $\mathrm{FeO}$. Most of the trace elements (Cd, Cr, Dy, Er, Eu, Ga, Gd, Ho, Lu, Nd, Pr, Sm, Sn, Sr, Tb, Tm, Y, Yb, Zr) are compatible with tremolite crystallized under hydrothermal transformation of ultramafic rocks.

The silica-rich fluid and the lime-rich one contained some amounts of $\mathrm{Na}, \mathrm{Rb}, \mathrm{Sr}, \mathrm{K}, \mathrm{Ce}$ and $\mathrm{Ba}$, and their metasomatism or contamination effect would have resulted in an increase in the mentioned element concentrations. Thus the poor Rb, Sr, Y, K, Ba and $\mathrm{Zr}$ and high Ni, Cr, Co contents of the rocks cannot be reconciled with the hydrothermal alteration, but point to depleted peridotites (harzburgite - lherzolite) and pyroxenite as protoliths.

Ongoing geological prospecting has revealed many more important talc schist deposits and related ultramafic rocks. These ultramafic rocks and the neighbouring migmatitic gabbroic massives intercalated in the Pan-African mica schists in Cameroon can be interpreted in terms of slices of a PanAfrican ophiolite set.

\section{Acknowledgements:}

The authors greatly appreciate the help of Gilles Lecomte (Ecole Nationale Supérieure de Céramique Industrielle, Limoges - France) for thermal analyses and Elie Kamseu (Mission de Promotion des Matériaux Locaux, Yaoundé - Cameroon) for sequential thermogravimetric analyses between 1050 and $1250{ }^{\circ} \mathrm{C}$. Financial supports of the University of Yaoundé I (Cameroon) and of the Ministry of Higher Education of Cameroon to the first author are greatly appreciated. Stays of the first author at "Laboratoire Environnement et Minéralurgie" (Nancy) were granted by "Mission de Coopération Française au Cameroun" and then by the "Centre National de Recherche Scientifique" (France). Thorough reviews by Pat Eriksson, F. Martin and an anonymous reviewer were extremely helpful. 


\section{REFERENCE}

Bose K. \& Ganguly J., 1994. Thermogravimetric study of dehydration kinetics of talc. American Mineralogist, 79, 7-8, $692-699$.

De Donato P., Cheilletz A., Barres O., Yvon J., 2004. Infrared spectroscopy of OD vibrators in minerals at natural dilution : hydroxyl groups in talc and kaolinite, and structural water in beryl and emerald. Applied Spectroscopy, 58, 5, 521-527.

De Donato, Ph., Villiéras F., Barres O. and Yvon J., 1993. Sur la possibilité d'observer les vibrations de valence OD aux dilutions naturelles : apport de la spectrométrie IRTF en réflexion diffuse. $C$. R. Acad. Sci. Paris, 316, Série II, 1757 - 1762.

Deer W.A., Howie R.A. \& Zussman J. 1992. An introduction to the rock-forming minerals, Longman publisher, London, 696 .

Della Ventura G., Hawthorne F.C., Robert J.-L. \& Iezzi G., 2003. Synthesis and infrared spectroscopy of amphiboles along the tremolite-pargasite join. European Journal of Mineralogy, 2, 341 347.

Elimbi A. \& Njopwouo D., 2002. Propriétés des produits de cuisson de deux argiles kaolinitiques de l'Ouest du Cameroun. Silicates Industriels, 66, 9-10, 121 - 125.

Farmer V.C., 1974. The layer silicates. In V.C. Farmer, Ed., The Infrared spectra of minerals, 331 364. Mineralogical Society, London.

Ferrage E., Martin F., Micoud P., Petit S., de Parseval P., Beziat D., Ferret J., 2003a. Cation site distribution in clinochlores: a NIR approach. Clay Minerals, 38, 331-340.

Ferrage E., Martin F., Petit S., Pejo-Soucaille S., Micoud P., Fourty G., Ferret J., Salvi S., de Parseval P., Fortune J.P., 2003b. Evaluation of talc morphology using FTIR and H/D substitution. Clay Minerals, 38, 141-150.

Feybesse J.L., Johan V., Maurizot P. \& Abessolo A., 1987. Evolution tectonométamorphique libérienne et éburnéenne de la partie NW du craton zaïrois (SW Cameroun). In : G. Matheis \& H Schandelmeier (Editors), Current Research in African Earth Sciences, Balkema, Rotherdam, pp $9-12$.

Frost R. L., Kloprogge J. T., 1999. Infrared emission spectroscopic study of brucite. Spectrochimica Acta. Part A, 55, 2195-2205.

Gehring A.U. \& Hofmeister A.M., 1994. The transformation of lepidocrocite during heating : a magnetic and spectrocopic study. Clays and Clay Minerals, 42, 4, 409- 415.

Ghose S., 1981. Subsolidus reactions and microstructures in amphiboles. In : D. R. Veblen (ed), Reviews in Mineralogy, vol 9A, Min. Soc. America, pp 325 - 372.

Laplaine L., 1969. Indices minéraux et ressources minérales du Cameroun. Bulletin de la Direction des Mines et de la Géologie, Cameroun, $N^{\circ}$ 5, $1-184$. 
Lappi S.E., Smith B., Franzen S., 2004. Infrared spectra of $\mathrm{H}_{2}{ }^{16} \mathrm{O}, \mathrm{H}_{2}{ }^{18} \mathrm{O}$ and $\mathrm{D}_{2} \mathrm{O}$ in the liquid phase by single-pass attenuated total internal reflection spectroscopy. Spectrochimica Acta, Part A, 60, 2611-2619.

Lasserre M. \& Soba D., 1976. Migmatisation d'âge panafricain au sein des formations camerounaises appartenant à la zone mobile d'Afrique Centrale. Comptes Rendus sommaires de la Société Géologique de France, 2, 64 - 68.

Leake B.E., Woollet A.R., Arps C.E.S., Birch W.D., Gilbert M.C., Grice J.D., Hawthorne F.C., Kato A., Kisch H.J., Krivovichev V.G., Linthout K., Laird J., Mandarino J., Maresch W.V.; Nickel E.H., Rock N.M.S., Schumacher J.C., Smith D.C., Stephenson N.C.N., Ungaretti L, Whittaker E.J.W. \& Youzhi G. 1997. Nomenclature of amphiboles report of the subcommittee on Amphiboles of the International Mineralogical Association Commission on New Minerals and Mineral Names, European Journal of Mineralogy, 9, 623-651 .

Manceau A., Schlrgel M.L., Musso M., Sole V.A., Gauthier C., Petit P.E., Trolard, F., 2000. Crystal chemistry of trace elements in natural and synthetic goethite. Geochemica et Cosmochimica Acta, 64, 21, 3643-3661.

McDonough W. F. and Sun S.-s., 1995. The composition of earth. Chemical Geology, 120, 223 - 253.

Melcher F., Meisel T., Puhl J. and Koller F., 2002. Petrogenesis and geotectonic setting of ultramafic rocks in the Eastern Alps : constraints from geochemistry. Lithos, 65, 69-112.

Mével C., 2003. Serpentinization of abyssal peridotites at mid-ocean ridges. C. R. Geoscience, Paris, $335,825-852$.

Michot L., 1990. Propriétés pysico-chimiques superficielles du talc et de la chlorite. Thèse Doct. INPL, Loraine, Nancy, 1990, pp 285 + annexes 131 p.

Michot L., Yvon J., Cases J. M., Zimmermann J.-L. and Baeza R., 1990. Apparente hydrophobie du talc et affinité de l'azote pour ce minéral. C. R. Acad. Sci. Paris, 310, Série II, 1063 - 1068.

Michot L.J., Villiéras F., François M., Yvon J., Le Dred R., Cases J.M., 1994. The structural microscopic hydrophobicity of talc. Langmuir, 10, 3765-3773.

Moore D.M., Reynolds R.C., 1997. X-Ray Diffraction and the Identification and Analysis of Clay Minerals. Oxford University Press, second edition, 378p.

Müller W.F., Schmädicke E., Okrush M. \& Schüssler U., 2003. Intergrowths between anthophyllite, gedrite, calcic amphibole, cummingtonite, talc and chlorite in a metamorphosed ultramafic rock of the KTB pilot hole, Bavaria. European Journal Mineralogy, 15, 2, 295 - 307.

Mvondo H., den Brok S.W.J. \& Mvondo J., 2003. Evidence for symmetric extension and exhumation of the Yaounde nappe (Pan-African fold belt, Cameroon). Journal of African Earth Sciences, 36, $215-231$

Ndonguissop Z.H.P., Nkoumbou C., Mbogning M., Agbor B., Bat B., Seme Mouangue A.C., Simo E., Ayongaba B. \& Omgba C., 1999. Exploration of the Cobalt - Nickel bearing laterites of Nkamouna (Lomié region, South-East Cameroon). Geovic Technical report $N^{\circ} 4,68 p+300$ pages of logs + maps in the annex. 
Njopwouo D. 1984. Minéralogie et physico-chimie des argiles de Bomkoul et de Balengou (Cameroun). Utilisation dans la polymérisation du styrène et dans le renforcement du caoutchouc naturel, Thèse Doct. Etat. Fac. Sci., Univ. de Yaoundé, 300 p.

Njopwouo D., Roques G. \& Wandji R., 1987. A contribution to the study of the catalytic action of clays on the polymerization of styrene : I. Characterization of polystyrenes. Clay Minerals, 22, 145-156.

Njopwouo D., Roques G. \& Wandji R., 1988. A contribution to the study of the catalytic action of clays on the polymerization of styrene : II. Reaction mechanism. Clay Minerals, 23, 35-43.

Noack Y., Colin F., 1986. Chlorites and chloritic mixed-layer minerals in profiles on ultrabasic rocks from Moyango (Ivory Coast) and Angiquinho (Brazil). Clay Minerals, 21, 171-182.

Nzenti J.P., Barbey P., Macaudière J. \& Soba D., 1988. Origin and evolution of late precambrian highgrade Yaoundé gneisses. Precambrian Research, 38, 91 - 109.

Perez-Maqueda L.A., Duran A., Perez-Rodriguez J.L., 2005. Preparation of submicron talc particles by sonication. Applied Clay Science, 28, 245-255.

Petit S., Martin F., Wiewora A., De Parseval P., Decarreau A., 2004. Crystal chemistry of talc : a near infrared (NIR) spectroscopy study. American Mineralogist, 89, 319-326

Puhan D. \& Metz P., 1987. Experimental equilibrium data for the reactions 3 dolomite +4 quartz + $\mathrm{H}_{2} \mathrm{O} \leftrightarrow 1$ talc +3 calcite $+3 \mathrm{CO}_{2}$ and 5 talc +6 calcite +4 quartz $\leftrightarrow 3$ tremolite $+6 \mathrm{CO}_{2}+2 \mathrm{H}_{2} \mathrm{O}$ at a total gas pressure of 5000 bars. Neues Jahrbuch für Mineralogie, Monteshefte, 515 - 520 .

Sanchez-Soto P.J., Wiewiora A., Avilés M.A., Justo A., Pérez-Maqueda L.A., Pérez-Rodriguez J.L., Bylina P., 1997. Talc from Puebla de Lillo, Spain. II. Effect of dry grinding on particle size and shape. Applied Clay Science, 12, 297-312.

Schandl E.S., Gorton M.P. and Sharata N.A., 2002. The origin of major talc deposits in the Eastern Desert of Egypt : relict fragments of metamorphosed carbonate horizon ? Journal of African Earth Sciences, 34, 259 - 273.

Scholtzova E., Tunega D., Nagy L.T., 2003. Theoritical study of cation substitution in trioctahedral sheet of phyllosilicates. An effect on inner $\mathrm{OH}$ group. Journal of Molecular Structure (Theochem), 620, 1-8.

Seme Mouangue A.C., 1998. Géochimie, métamorphisme et métallogénie des latérites cobaltonickelifères développées sur les roches ultrabasiques du secteur de Lomié, (Est - Cameroun). Doct. $3^{\text {ème }}$ cycle, Univ. Yaoundé I, 155 p.

Tchameni R., 1997. Géochimie et géochronologie des formations de l'Archéen et du Paléoprotérozoïque du Sud-Cameroun (Groupe du Ntem, Craton du Congo). Thèse Doct. Univ. d'Orléans, France, pp 356 + annexes.

Toteu S.F., Van Schmus W.R., Penaye J. \& Nyobé J.B., 1994. U-Pb and Sm-Nd evidence for Eburnian and Pan-african high-grade metamorphism in cratonic rocks of southern Cameroon. Precambrian Research, 67, 321 - 347. 
Trommsdorf V., Evans B.W., 1977. Antigorite-Ophicarbonates: phase relations in a portion of the system $\mathrm{CaO}-\mathrm{MgO}-\mathrm{SiO}_{2}-\mathrm{H}_{2} \mathrm{O}-\mathrm{CO}_{2}$. Contribution to Mineralogy and Petrology, 60, 39-56.

Villiéras F., 1993. Etude des modifications des propriétés thermiques du talc et de la chlorite par traitement thermique. Thèse Doct. E.N.S.G., I.N.P.L., Nancy, France, tome 1, 248 p.

Weckler B., Lutz H.D., 1998. Lattice vibration spectra. Part XCV. Infrared spectroscopic studies on the iron oxide hydroxides goethite $(\alpha)$, akaganeite $(\beta)$, lepidocrocite $(\gamma)$, and feroxyhite $(\delta)$. European Journal of Solid State Inorganic Chemistry, 35, 531-544.

Wilkins R. W. T. \& Ito J., 1967. Infrared spectra of some synthetic talcs. American Mineralogist, 52, $1649-1661$.

Workman R. K., Hart S. R., 2005. Major and trace element composition of the depleted MORB mantle (DMM). Earth and Planetary Science Letters, 231, 53-72.

Yigitbas E., Kerrich R., Yilmaz Y., Elmas A. and Xie Q., 2004. Characteristics and geochemistry of precambrian ophiolites and related volcanics from the Istanbul-Zonguldak unit, Northwestern Anatolia, Turkey : following the missing chain of the precambrian South European suture zone to the east. Precambrian Research, 132, $179-206$.

Yvon J., Lietard O., Cases J. M., Delon J. F., 1982. Minéralogie des argiles kaoliniques des Charentes. Bulletin de Minéralogie, 105, 431-437.

Yvon J., Baudracco J., Cases J.M., Weiss J., 1990. Eléments de minéralogie quantitative en microanalyse des argiles. In : Matériaux Argileux, Structures, Propriétés et Applications. SFMC GFA, Paris. A Decarreau éd., ISBN 2-903589-06-02, Partie IV, Chap. 3, 473-489. 
Table 1: Coherent scattering thickness of talc (CSTT) and chlorite (CSTC). Data sources: MAMB \& 1GG (this study), 0083, 00C \& Besta50 (Michot, 1990), CV \& CN (Villiéras, 1993), Sp ${ }^{1}$ (SanchezSoto et al., 1997) and $\mathrm{Sp}^{2}$ (Perez-Maqueda et al., 2005).

\begin{tabular}{|l|r|r|r|r|r|r|r|r|r|}
\hline & MAMB & 1 GG & 0083 & $00 \mathrm{C}$ & Besta50 & CV & CN & Sp $^{1}$ & $\mathrm{Sp}^{2}$ \\
\hline CSTT $(\AA)$ & 1072 & 1062 & 411 & 371 & 445 & & 313 & 400 & 340 \\
\hline CSTC $(\AA)$ & 876 & 898 & 399 & 320 & 467 & 270 & 290 & & \\
\hline
\end{tabular}

Table 2 : Thermogravimetric analyses of talc schists and their interpretations.

\begin{tabular}{|c|r|c|l|}
\hline Sample & \multicolumn{1}{|c|}{$\begin{array}{c}\text { Temperature } \\
\text { range }\end{array}$} & $\begin{array}{c}\text { Weight } \\
\text { loss (\%) }\end{array}$ & \multicolumn{1}{|c|}{ Reactions } \\
\hline \multirow{4}{*}{ Mamb } & $20-150^{\circ} \mathrm{C}$ & 0.032 & Elimination of adsorbed water \\
\cline { 2 - 5 } & $200-325^{\circ} \mathrm{C}$ & 0.291 & Dehydroxylation of goethite and lepidocrocite \\
\cline { 2 - 5 } & $450-850^{\circ} \mathrm{C}$ & 0.230 & Dehydroxylation of chlorite \\
\cline { 2 - 5 } & $850-1050^{\circ} \mathrm{C}$ & 3.944 & Dehydoxylation of talc \\
\cline { 2 - 5 } & $1050-1250^{\circ} \mathrm{C}$ & 0.555 & Recrystallisation into enstatite and cristobalite \\
\hline \multirow{5}{*}{ GG } & $20-250^{\circ} \mathrm{C}$ & 0.021 & Elimination of adsorbed water \\
\cline { 2 - 5 } & $250-500^{\circ} \mathrm{C}$ & 0.138 & Dehydroxylation of goethite and lepidocrocite \\
\cline { 2 - 5 } & $500-825^{\circ} \mathrm{C}$ & 0.150 & Dehydroxylation of chlorite \\
\cline { 2 - 4 } & $825-1050^{\circ} \mathrm{C}$ & 3.550 & Dehydoxylation of talc \\
\cline { 2 - 4 } & $1050-1250^{\circ} \mathrm{C}$ & 0.491 & Recrystallisation into enstatite and cristobalite \\
\hline
\end{tabular}

Table 3: Estimated mineral proportions of talc schists from XRD, TG and chemical analyses (C.A.). * values including goethite and lepidocrocite.

\begin{tabular}{|l|r|r|r|r|r|r|}
\hline & \multicolumn{3}{|c|}{ MAMB } & \multicolumn{3}{c|}{1 GG } \\
\hline & XRD & \multicolumn{1}{|c|}{ TG } & C.A. & XRD & \multicolumn{1}{c|}{ TG } & C.A. \\
\hline Talc & 94.0 & 94.7 & 91.8 & 88.0 & 85.1 & 84.6 \\
\hline Chlorite & 2.0 & 1.8 & 4.3 & 2.0 & 1.2 & 4.1 \\
\hline Tremolite & & & & 4.0 & n.d. & 9.1 \\
\hline Goethite & 1.0 & $* 2.9$ & $* 3.8$ & & & \\
\hline Lepidocrocite & 1.0 & & & 1.0 & 1.4 & 0.2 \\
\hline Unknown & 2.0 & 0.6 & 0.1 & 5.0 & 12.3 & 2.0 \\
\hline
\end{tabular}


Table 4: Chemical analyses (major elements in wt \%) of talc schists (1GG, MAMB), hornblendite (PK3) and separated tremolite (1MM) and its structural formula.

\begin{tabular}{|c|c|c|c|c|c|c|c|}
\hline \multicolumn{4}{|c|}{ Whole rocks } & \multicolumn{4}{|c|}{ Separated Tremolite } \\
\hline Oxides & $1 \mathrm{GG}$ & MAMB & PK3 & Oxides & $1 \mathrm{MM}$ & Struct & mula \\
\hline $\mathrm{SiO}_{2}$ & 59.14 & 58.74 & 57.30 & $\mathrm{SiO}_{2}$ & 53.10 & $\mathrm{Si}$ & 7.447 \\
\hline $\mathrm{Al}_{2} \mathrm{O}_{3}$ & 1.18 & 0.79 & 4.26 & $\mathrm{Al}_{2} \mathrm{O}_{3}$ & 3.39 & $\mathrm{Al}$ & 0.500 \\
\hline $\mathrm{Fe}_{2} \mathrm{O}_{3}$ & 5.73 & 6.68 & 8.06 & $\mathrm{Fe}_{2} \mathrm{O}_{3}$ & 8.37 & $\mathrm{Fe}^{3+}$ & 0.474 \\
\hline $\mathrm{MnO}$ & 0.08 & 0.11 & 0.21 & $\mathrm{MnO}$ & 0.26 & $\mathrm{Fe}^{2+}$ & 0.500 \\
\hline $\mathrm{MgO}$ & 27.54 & 28.51 & 17.42 & $\mathrm{MgO}$ & 19.37 & $\mathrm{Mn}$ & 0.031 \\
\hline $\mathrm{CaO}$ & 1.09 & $<$ I.d. & 10.23 & $\mathrm{CaO}$ & 11.87 & $\mathrm{Mg}$ & 4.044 \\
\hline $\mathrm{Na}_{2} \mathrm{O}$ & 0.06 & $<$ I.d. & 0.45 & $\mathrm{Na}_{2} \mathrm{O}$ & 0.55 & $\mathrm{Ca}$ & 1.756 \\
\hline $\mathrm{K}_{2} \mathrm{O}$ & $<$ I.d. & $<$ I.d. & $<$ I.d. & $\mathrm{K}_{2} \mathrm{O}$ & $<$ I.d. & $\mathrm{Na}$ & 0.150 \\
\hline $\mathrm{TiO}_{2}$ & $<$ I.d. & $<$ I.d. & 0.12 & $\mathrm{TiO}_{2}$ & $<$ I.d. & $\mathrm{P}$ & 0.010 \\
\hline $\mathrm{P}_{2} \mathrm{O}_{5}$ & 0.08 & 0.09 & $<$ I.d. & $\mathrm{P}_{2} \mathrm{O}_{5}$ & 0.08 & $\mathrm{Cr}$ & 0.103 \\
\hline $\mathrm{Cr}_{2} \mathrm{O}_{3}$ & 0.53 & 0.53 & 0.76 & $\mathrm{Cr}_{2} \mathrm{O}_{3}$ & 0.90 & $\mathrm{Ni}$ & 0.010 \\
\hline $\mathrm{NiO}$ & 0.26 & 0.25 & 0.09 & $\mathrm{NiO}$ & 0.11 & & \\
\hline P.F. & 4.35 & 4.78 & 2.21 & P.F. & 2.04 & & \\
\hline Total & 100.04 & 100.48 & 101.06 & Total & 100.04 & & \\
\hline
\end{tabular}


Table 5: Trace elements (ppm) of talc schists (1GG, MAMB), hornblendite (PK3) and separated tremolite (1MM), and amphibole/whole-rock partition coefficients $(\mathrm{Kd}=1 \mathrm{MM} / 1 \mathrm{GG}),{ }^{*} \mathrm{Cr}$ and $\mathrm{Ni}$ have been recalculated as oxides due to their high values (see major elements).

\begin{tabular}{|c|c|c|c|c|c|}
\hline & $1 \mathrm{GG}$ & MAMB & PK3 & $1 \mathrm{MM}$ & $\mathrm{Kd}$ \\
\hline As & $<$ I.d. & $<$ I.d. & $<$ I.d. & $<$ I.d. & \\
\hline $\mathrm{Ba}$ & 16.4 & 12.5 & 19.6 & 9.7 & 0.6 \\
\hline $\mathrm{Be}$ & $<$ I.d. & $<$ I.d. & 0.57 & $<$ I.d. & \\
\hline $\mathrm{Bi}$ & $<$ I.d. & 1.29 & $<$ I.d. & $<$ I.d. & \\
\hline $\mathrm{Cd}$ & $<$ I.d. & $<$ I.d. & $<$ I.d. & 0.48 & \\
\hline $\mathrm{Ce}$ & 16.0 & 4.38 & 18.7 & 5.16 & 0.3 \\
\hline Co & 99.7 & 89.2 & 73.3 & 58.5 & 0.6 \\
\hline${ }^{*} \mathrm{Cr}$ & 3597 & 3606 & 5158 & 6178 & 1.7 \\
\hline Cs & $<$ I.d. & $<$ I.d. & $<$ I.d. & $<$ I.d. & \\
\hline $\mathrm{Cu}$ & $<$ I.d. & 25.6 & 35.8 & $<$ I.d. & \\
\hline Dy & $<$ I.d. & 0.102 & 1.57 & 0.481 & \\
\hline Er & 0.051 & 0.072 & 0.947 & 0.462 & 9.1 \\
\hline $\mathrm{Eu}$ & $<$ I.d. & $<$ I.d. & 0.385 & 0.197 & \\
\hline $\mathrm{Ga}$ & 2.16 & 2.59 & 8.35 & 8.51 & 3.9 \\
\hline $\mathrm{Gd}$ & 0.172 & $<$ I.d. & 1.46 & 0.454 & 2.6 \\
\hline $\mathrm{Ge}$ & 2.51 & 3.08 & 2.28 & 3.16 & 1.3 \\
\hline $\mathrm{Hf}$ & $<$ I.d. & $<$ I.d. & 0.42 & 0.09 & \\
\hline Но & 0.022 & 0.024 & 0.309 & 0.143 & 6.5 \\
\hline In & $<$ I.d. & $<$ I.d. & 0.09 & 0.10 & \\
\hline $\mathrm{La}$ & 0.281 & 0.459 & 10.4 & 0.392 & 1.4 \\
\hline $\mathrm{Lu}$ & 0.015 & 0.031 & 0.175 & 0.106 & 7.1 \\
\hline Mo & $<$ I.d. & $<$ I.d. & $<$ I.d. & $<$ I.d. & \\
\hline $\mathrm{Nb}$ & $<$ I.d. & $<$ I.d. & 0.52 & $<$ I.d. & \\
\hline $\mathrm{Nd}$ & 0.428 & 0.511 & 9.11 & 0.857 & 2.0 \\
\hline *Ni & 2050 & 1994 & 719 & 862 & 0.4 \\
\hline $\mathrm{Pb}$ & 1.66 & $<$ I.d. & 3.57 & 1.67 & 1 \\
\hline $\mathrm{Pr}$ & 0.106 & 0.142 & 2.63 & 0.203 & 1.9 \\
\hline $\mathrm{Rb}$ & $<$ I.d. & $<$ I.d. & 2.56 & $<$ I.d. & \\
\hline $\mathrm{Sb}$ & $<$ I.d. & 0.22 & $<$ I.d. & $<$ I.d. & \\
\hline $\mathrm{Sm}$ & 0.077 & 0.107 & 1.75 & 0.450 & 5.8 \\
\hline $\mathrm{Sn}$ & $<$ I.d. & $<$ I.d. & 2.83 & 4.06 & \\
\hline $\mathrm{Sr}$ & $<$ I.d. & $<$ I.d. & 19.0 & 6.9 & \\
\hline $\mathrm{Ta}$ & $<$ I.d. & $<$ I.d. & 0.04 & $<$ I.d. & \\
\hline $\mathrm{Tb}$ & 0.013 & 0.021 & 0.253 & 0.076 & 5.8 \\
\hline Th & 0.10 & $<$ I.d. & 0.09 & 0.14 & 1.4 \\
\hline $\mathrm{Tm}$ & 0.012 & 0.013 & 0.160 & 0.087 & 7.25 \\
\hline $\mathrm{U}$ & $<$ I.d. & $<$ I.d. & 0.05 & $<$ I.d. & \\
\hline V & $<$ I.d. & $<$ I.d. & 85.1 & $<$ I.d. & \\
\hline $\mathrm{W}$ & $<$ I.d. & $<$ I.d. & 0.27 & $<$ I.d. & \\
\hline$Y$ & 0.51 & 0.68 & 9.21 & 4.79 & 9.4 \\
\hline $\mathrm{Yb}$ & 0.068 & 0.100 & 1.18 & 0.667 & 9.8 \\
\hline $\mathrm{Zn}$ & 268 & $\begin{array}{l}59.8 \\
\end{array}$ & 116 & 179 & 0.7 \\
\hline $\mathrm{Zr}$ & $<$ I.d. & 0.86 & 15.9 & 2.87 & \\
\hline
\end{tabular}




\section{FIGURE CAPTIONS}

Figure 1a: Sketch geological map. 1, Archean Ntem unit; 2, Eburnean Ayna and Lower Nyong units, respectively east and west of Ntem unit; 3, Dja series; 4, neoproterozoic basins; 5, pan-african belt; 6, ophiolitic sets; 7, Mesozoic sediments; 8, Cenozoic volcanic rocks of the Cameroon Line and the Adamawa plateau; 9, thrusts; 10 faults: TBSZ, Tcholiré-Banyo shear zone; CCSZ, Central Cameroon shear zone; SSZ, Sanaga shear zone; SCSZ, Southwest Cameroon shear zone. The square NPB indicates the studied area.

Figure 1b: Geological map of talc deposits at Lamal Pougue. 1. Mica schists, 2. talc deposits (a: studied talc schist, b, c, d \& e: new discoveries), 3. amphibole-pyroxenite, 4. quartzites, 5. plagioclase-hornblendite, 6 . ortho-amphibolite, 7. gneiss, 8 a. schistosity, b. lineation, c. road and path.

Figure 2: Photomicrographs of talc schists. A, Coarse-grained talc schist from Lamal Pougue, width of field: $2.64 \mathrm{~mm}, \mathrm{~B}$, Talc schist from Pout-Kelle showing euhedral tremolite crystals developed at the expense of talc. The microcrystalline matrix is made up of talc and accessory chlorite (see text). C \& $\mathrm{D}$, Detail of B under polarized and cross-polarized light, respectively. Tremolite crystal growth is obvious at the pyramidal edge, width of the field: $0.66 \mathrm{~mm}$.

Figure 3: X-ray patterns, a: diffractograms of talc schists, $\mathrm{x}$ axis of sample Mamb is shifted along y axis to 2000 , b: diffractogram of tremolite showing talc fingerprint (see text), c: diffractogram of magnesio-riebeckite.

Figure 4: Differential thermal analyses of $1 \mathrm{GG}$ and Mamb talc schists.

Figure 5: Thermogravimetric analyses of $1 \mathrm{GG}$ and Mamb talc schists.

Figure 6: Diffuse Reflectance Infrared Fourier Transform Spectroscopy patterns. a: talc schists. The insert is a blow up of sections $1 \& 2$ to show distinct absorption bands of talc (see text) and associated minerals (brucite : $3697 \mathrm{~cm}^{-1}$, chlorite : $3610,3589 \mathrm{~cm}^{-1}$ ). b: Separated tremolite (1MM) and Magnesio-riebeckite (1NT). The insert is a blow up of sections $1 \& 2$ to show the main absorption band at $3674 \mathrm{~cm}^{-1}$ and satellite bands.

Figure 7: Partition coefficients of extended REE between amphibole and talc schist.

Figure 8: REE pattern. 1GG, talc schist from Pout-Kelle; Mamb, talc schist from Lamal Pougue; $1 \mathrm{MM}$, tremolite; PK3, hornblendite sampled near the talc schist of Pout-Kelle. 
Figure 9 : Spider diagrams of whole rocks and separated tremolite. DMM: Depleted Morb Mantle (Workman and Hart, 2005), See legend in figure 8.

\section{TABLE CAPTIONS}

Table 1: Domains of coherent scattering of talc (DCT) and chlorite (DCC). Data sources: MAMB \& 1GG (this study), 0083, 00C \& Besta50 (Michot, 1990), CV \& CN (Villiéras, 1993), Sp ${ }^{1}$ (Sanchez-Soto et al., 1997), Sp² (Perez-Maqueda et al., 2005).

Table 2: Thermogravimetric analyses of talc schists and their interpretations.

Table 3: Estimated mineral proportions of talc schists from XRD, TG and chemical analyses (C.A.). * values including goethite and lepidocrocite.

Table 4: Chemical analyses of talc schists (1GG, MAMB), hornblendite (PK3) and separated tremolite $(1 \mathrm{MM})$ and its structural formula.

Table 5: Trace elements (ppm) of talc schists (1GG, MAMB), hornblendite (PK3) and separated tremolite (1MM), and amphibole/whole-rock partition coefficients $(\mathrm{Kd}=1 \mathrm{MM} / 1 \mathrm{GG}),{ }^{*} \mathrm{Cr}$ and $\mathrm{Ni}$ have been recalculated as oxides due to their high values (see major elements). 


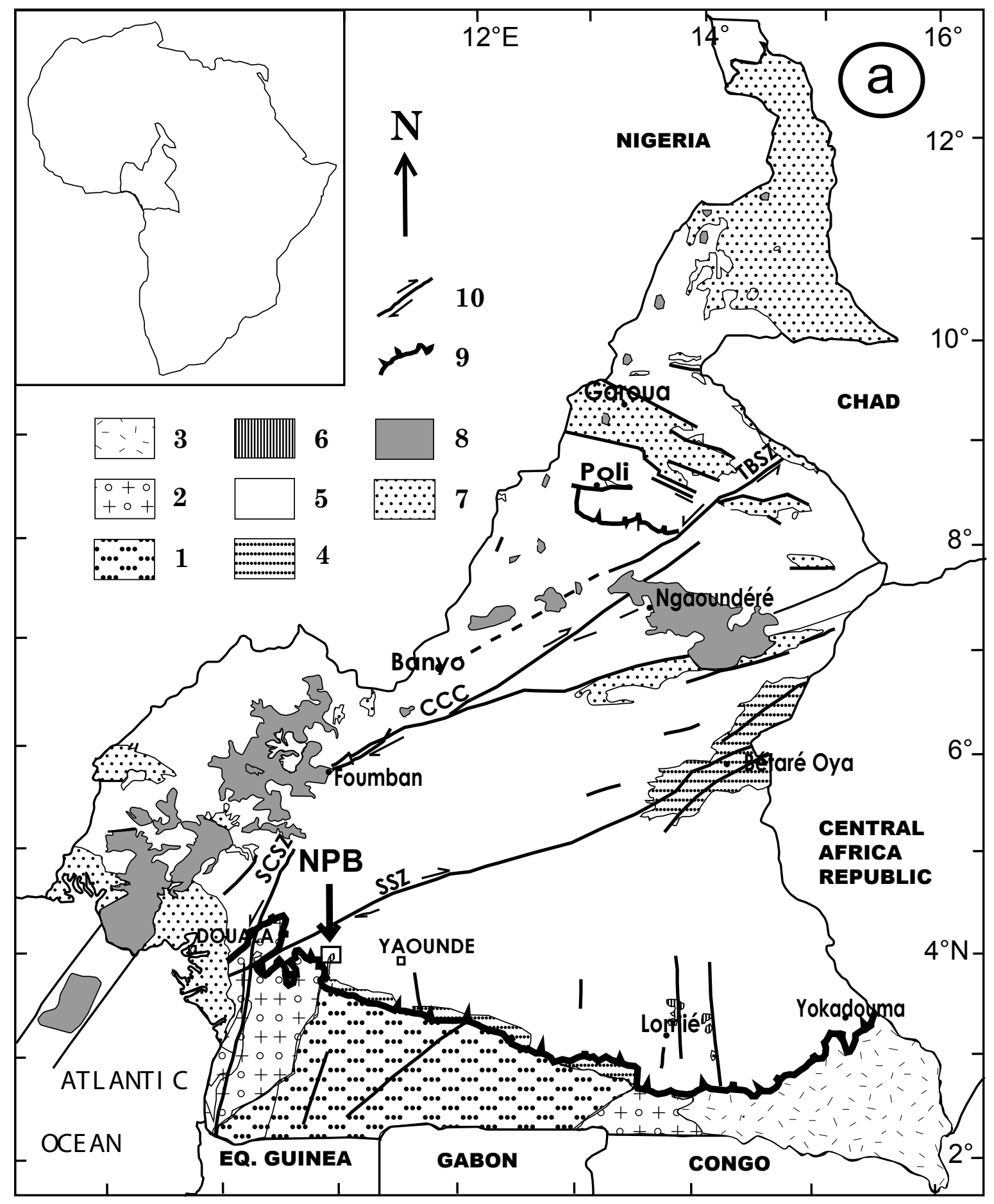




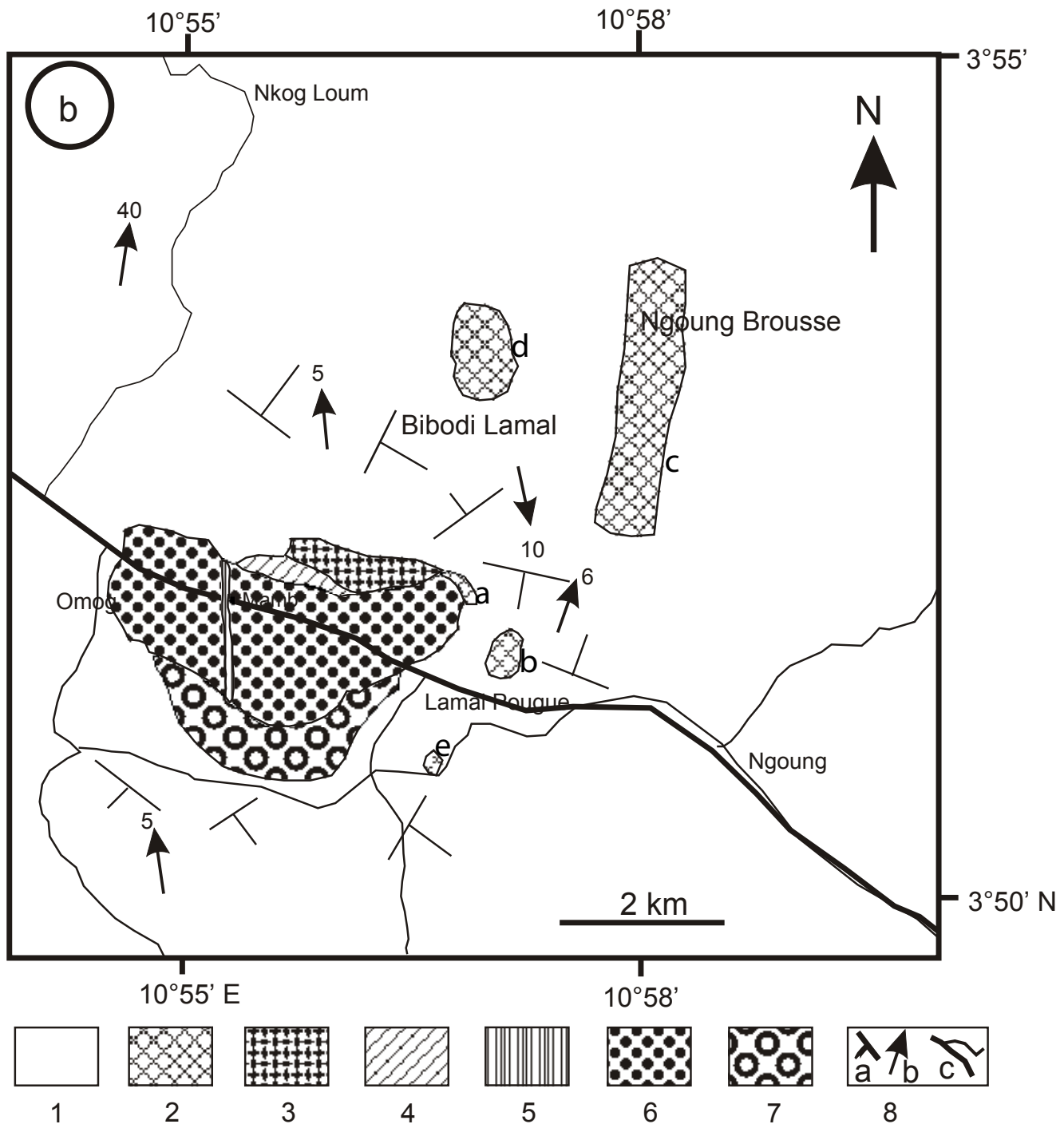



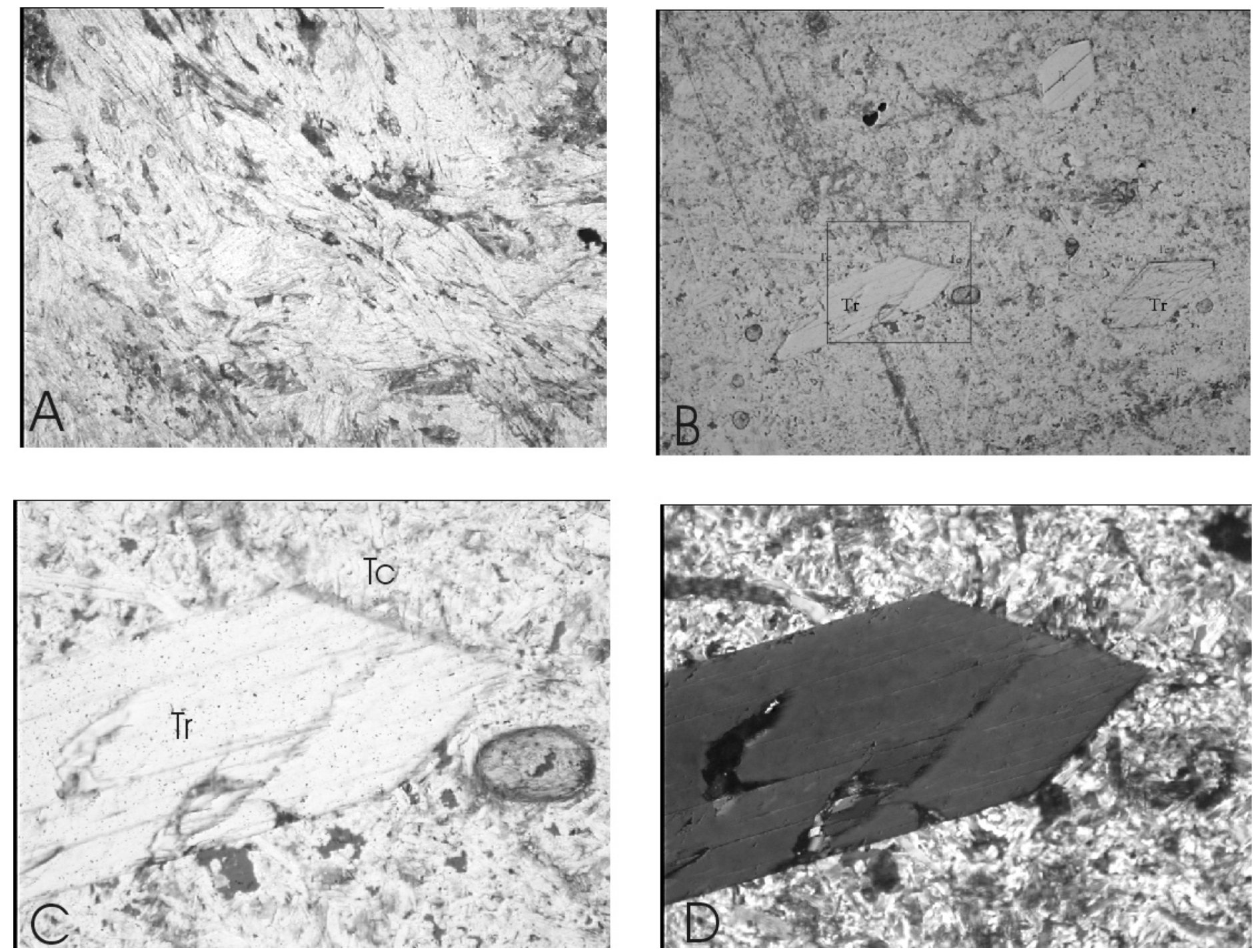


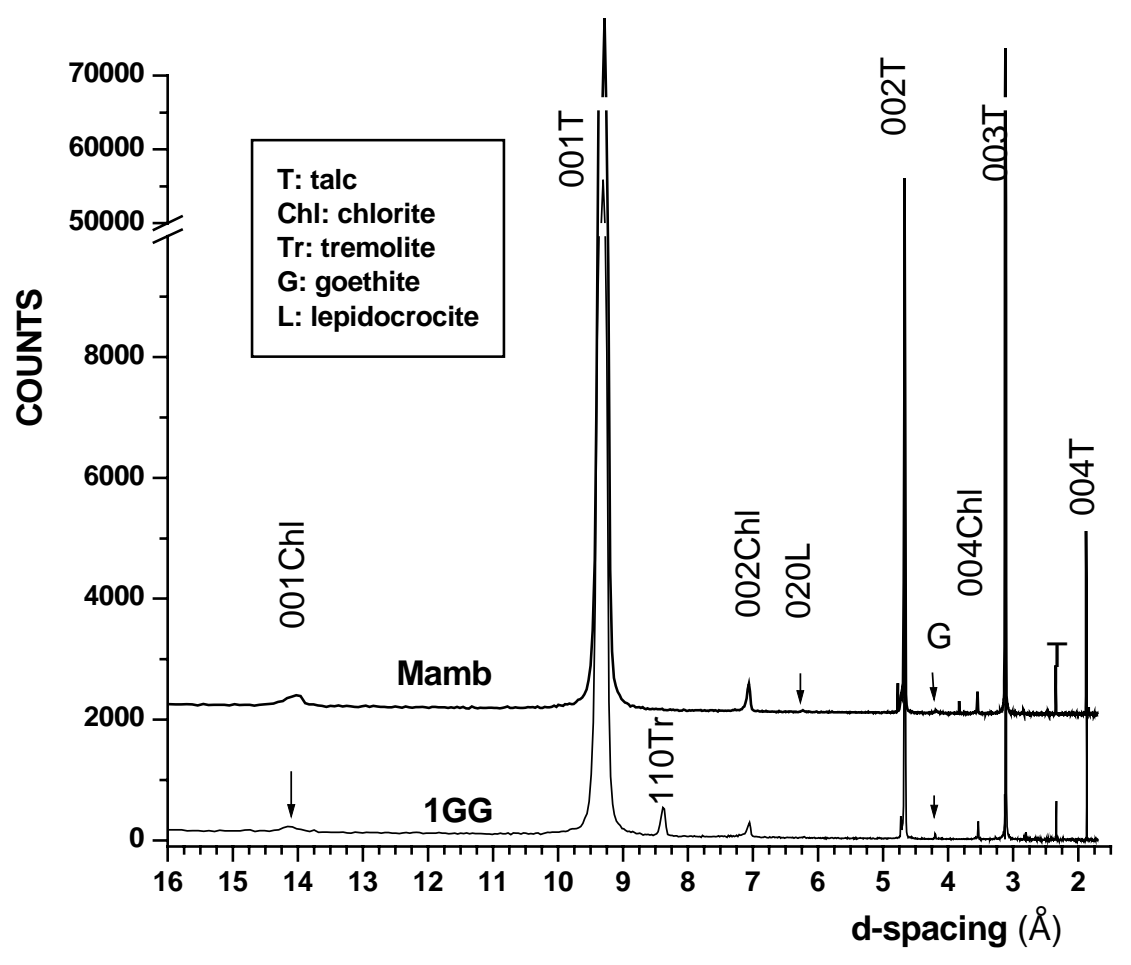

Figure 3a

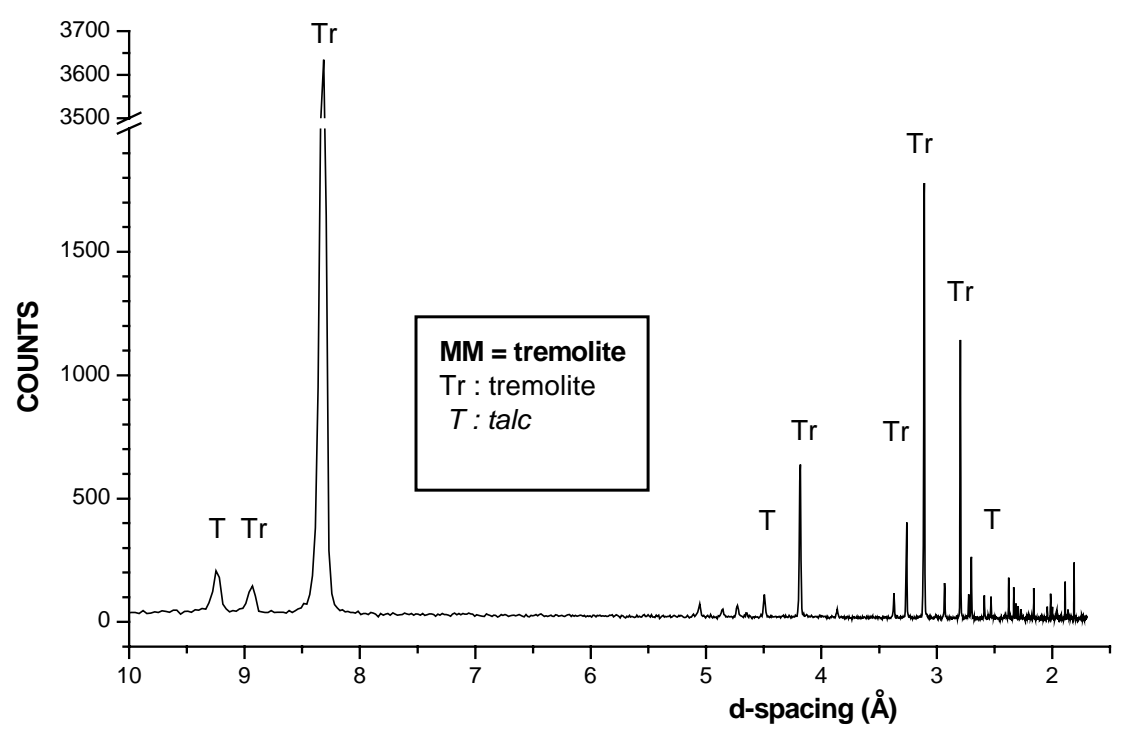

Figure 3b 


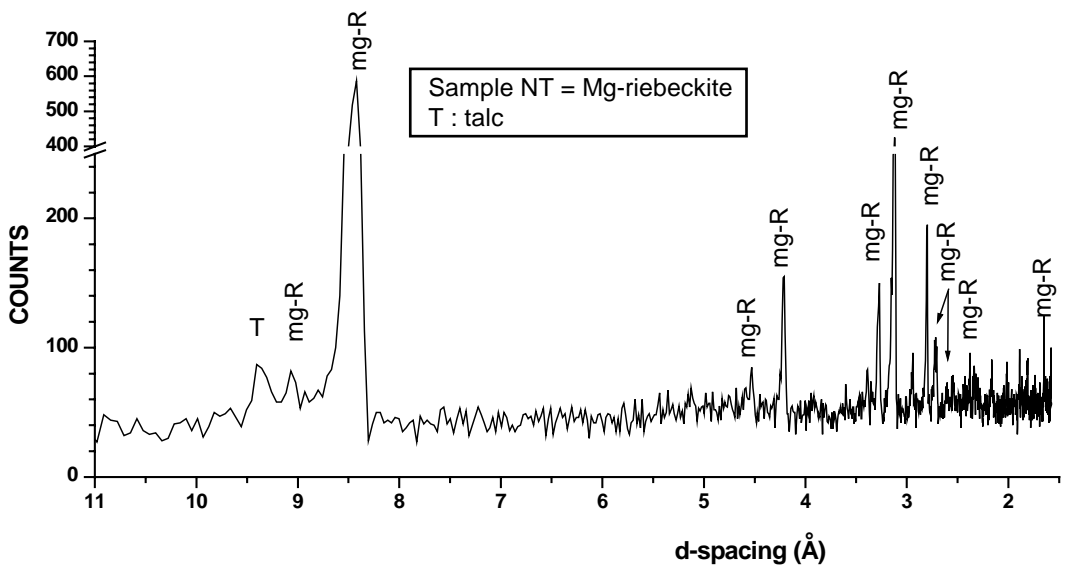

Figure 3c

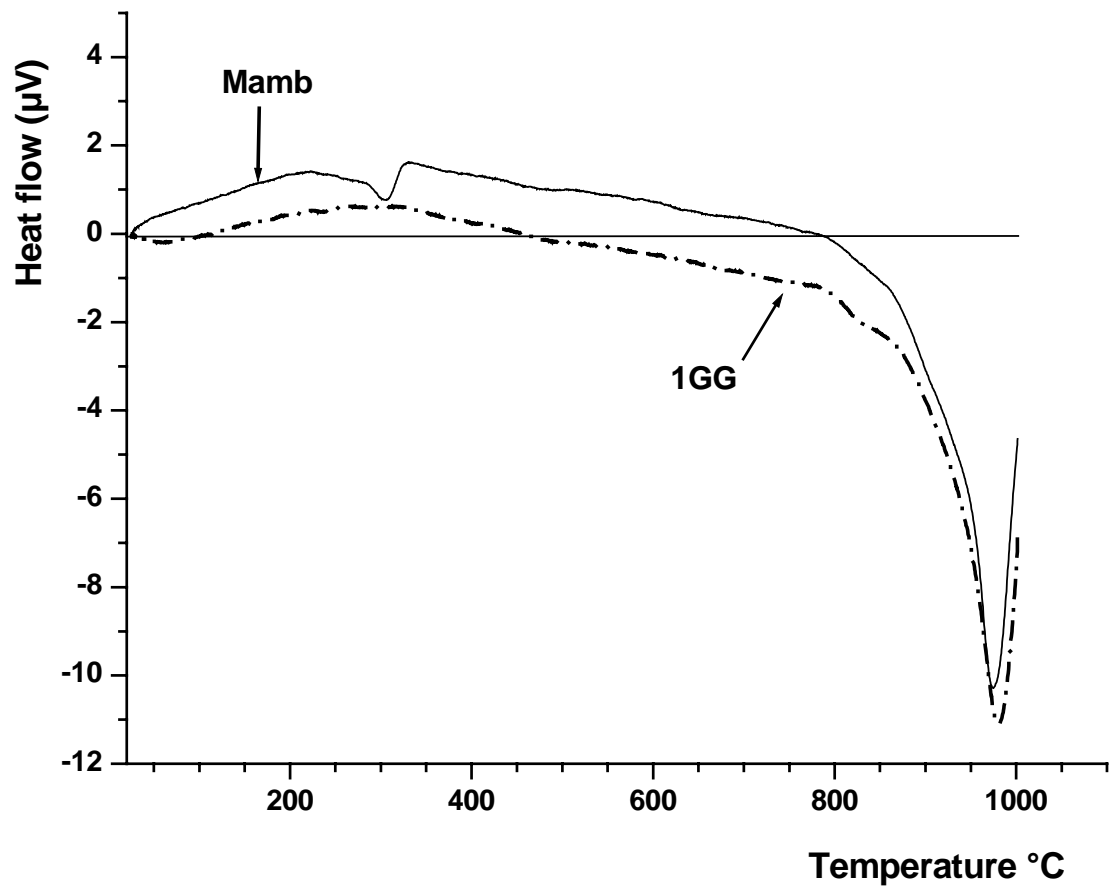

Figure 4 


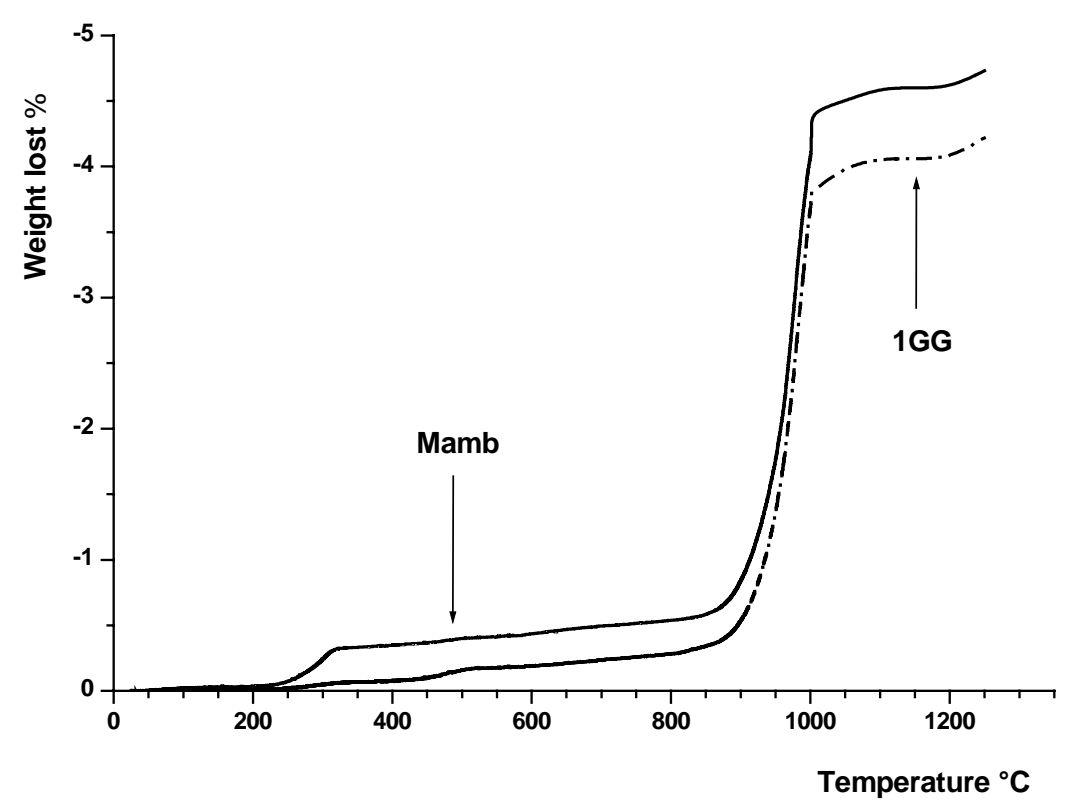

Figure 5

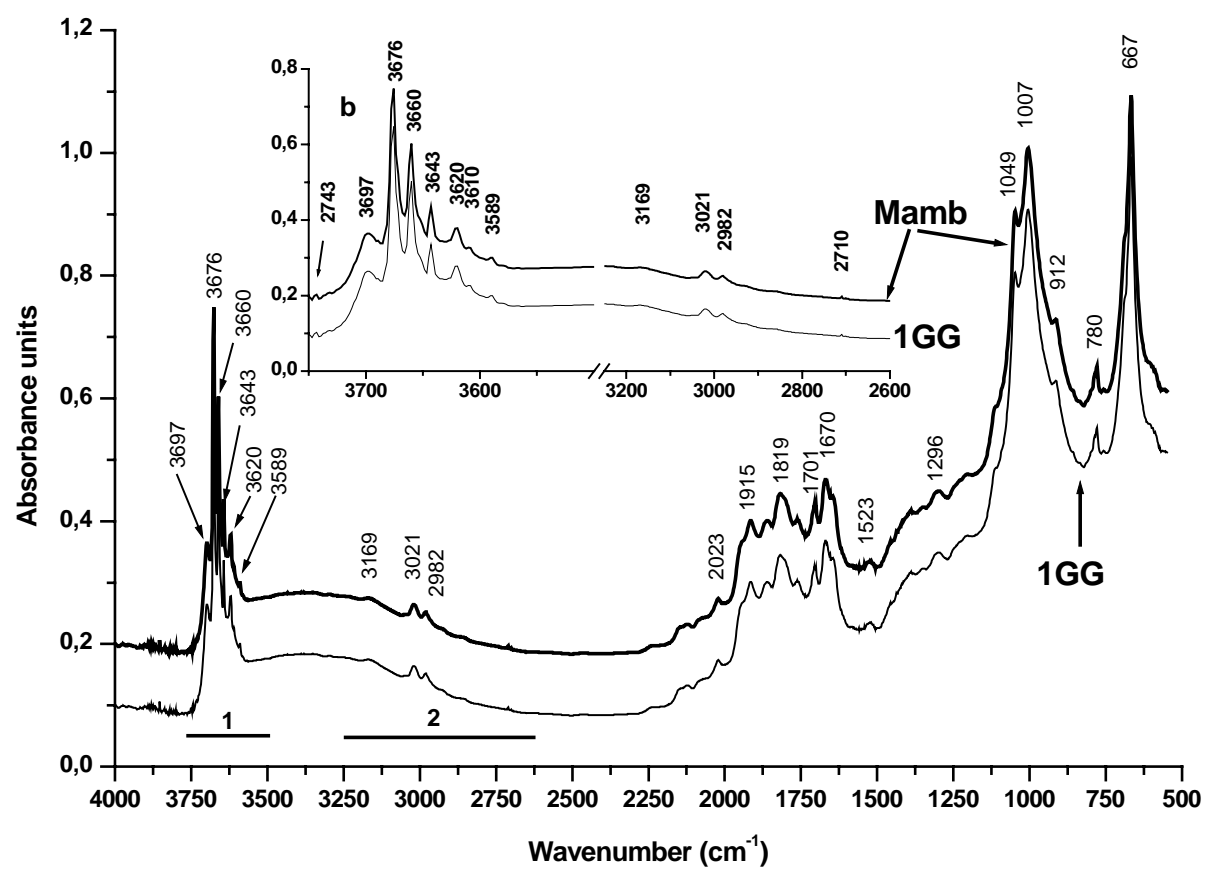

Figure 6a 


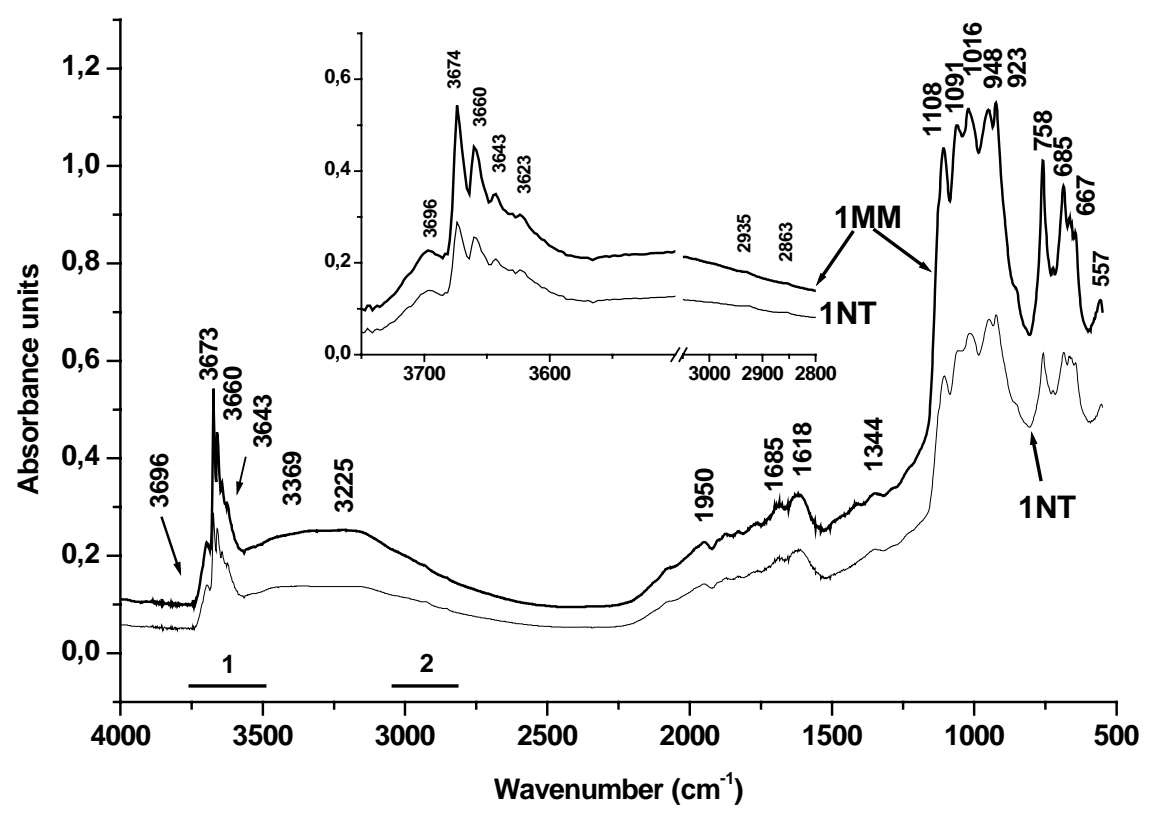

Figure 6b

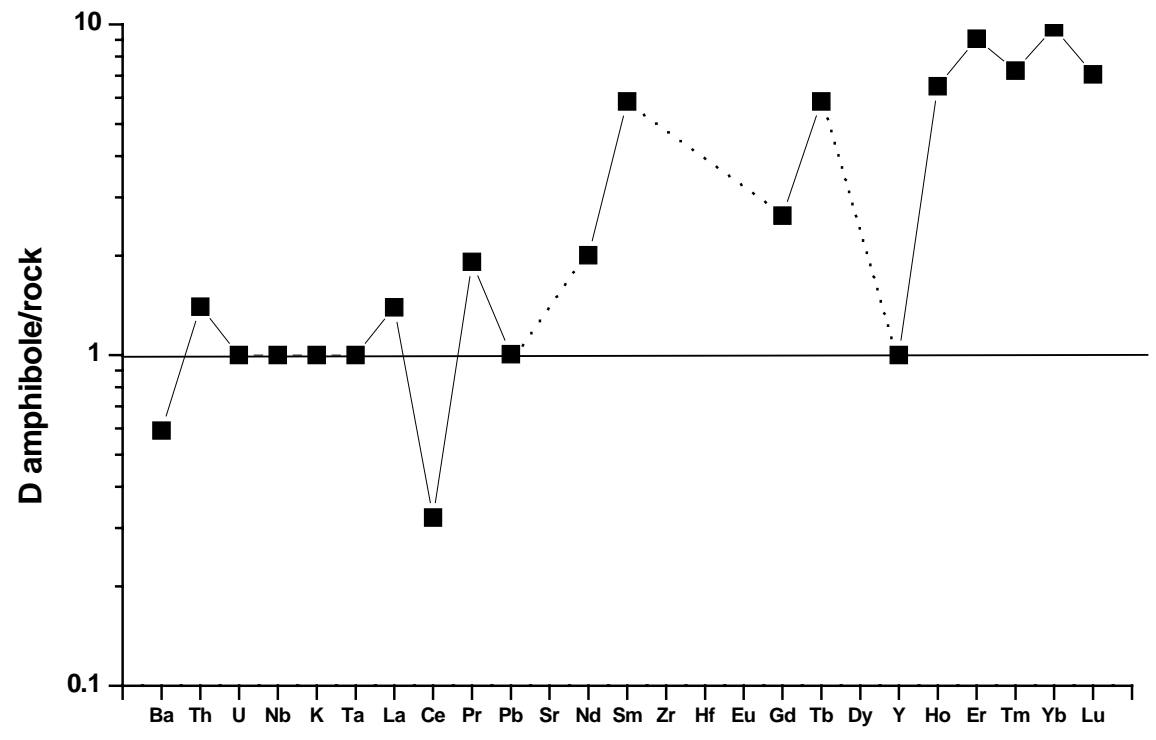

Figure 7 


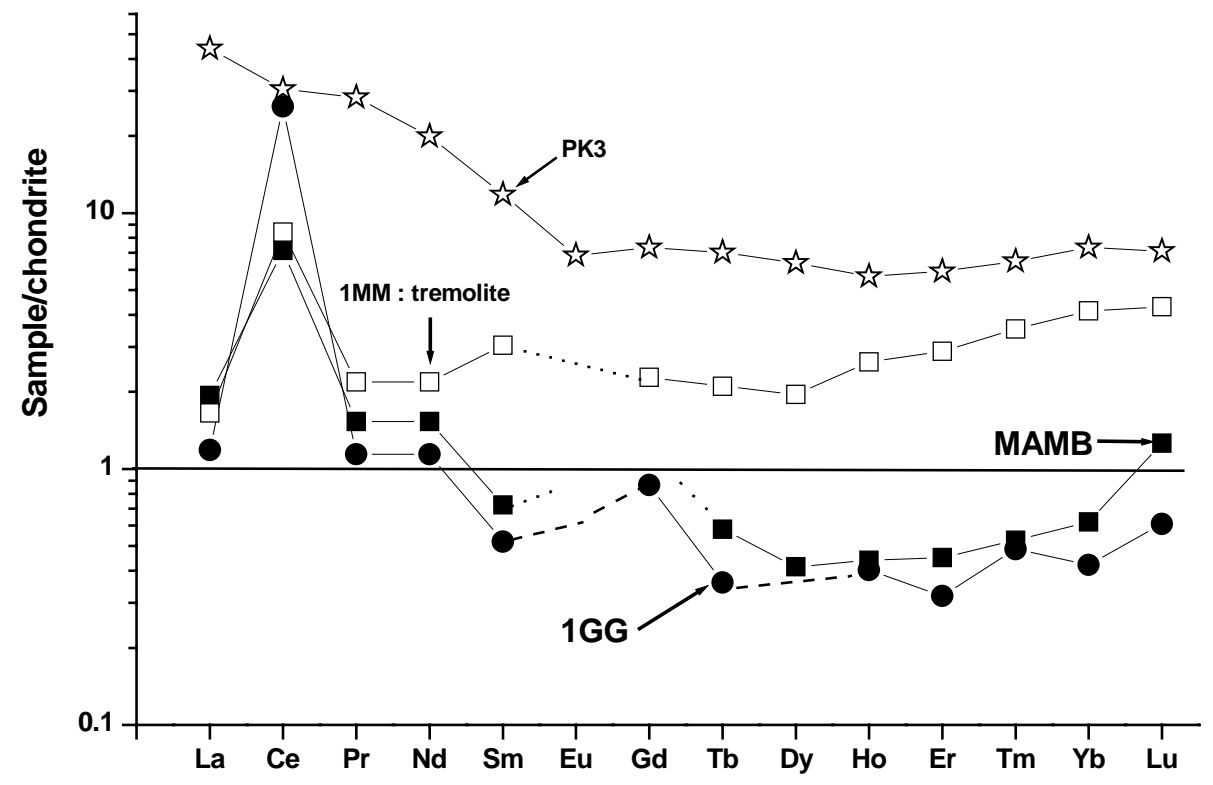

Figure 8

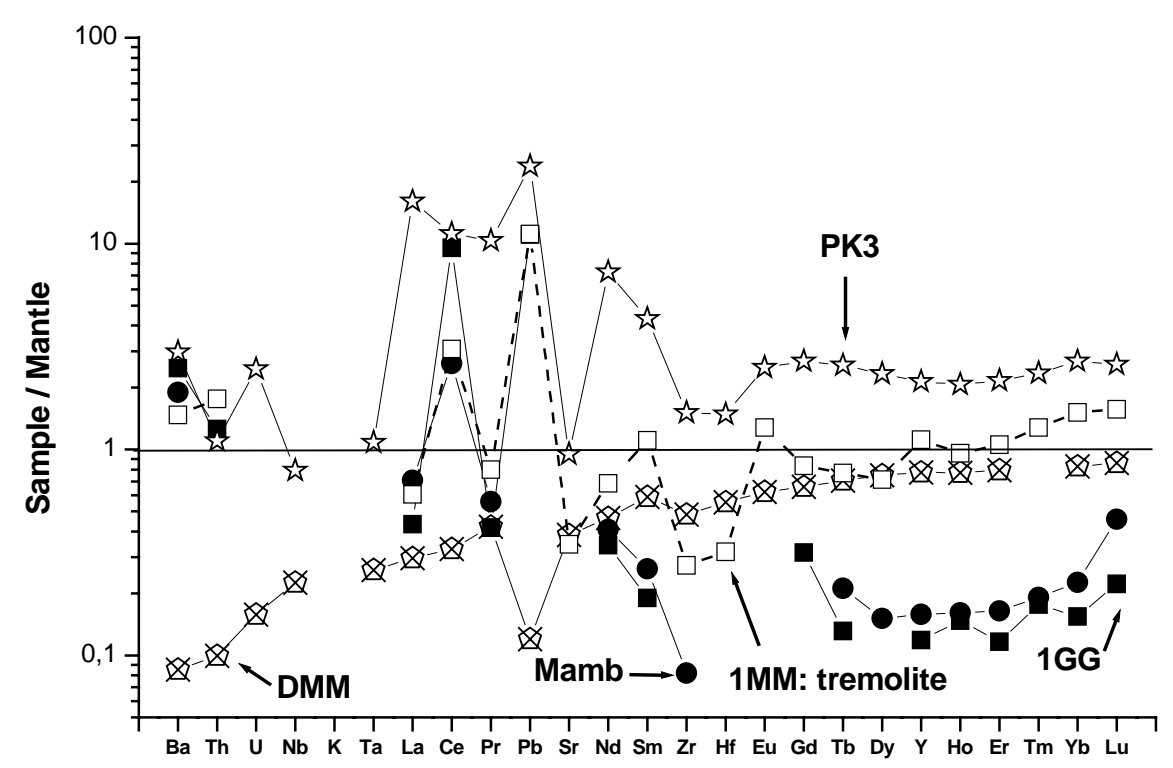

Figure 9 